VOX PATRUM $38(2018)$ t. 70

Jacek WIEWIOROWSKI*

\title{
KOLORYSTYKA SZCZEGÓLÓW GEOGRAFICZNYCH W NOTITIA DIGNITATUM PARS ORIENTIS WEDLUG RĘKOPISÓW OXONIENSIS CANONICIANUS MISC. 378 I MONACENSIS LATINUS 10291 ${ }^{1}$
}

Pochodząca z przełomu IV I V w. Notitia omnium dignitatum et administrationum tam civilium quam militarium (Laterculus maius) jest zestawieniem wyższych urzędników cesarskich w imperium zachodniorzymskim i wschodniorzymskim ${ }^{2}$. Obejmuje ona też służący im personel pomocniczy w ramach officium

${ }^{*}$ Dr hab. Jacek Wiewiorowski, prof. UG - Kierownik Zakładu Prawa Rzymskiego na Wydziale Prawa i Administracji Uniwersytetu Gdańskiego; e-mail: jacek.wiewiorowski@prawo.ug.edu.pl.

${ }^{1}$ W tekście uwzględniono edycje: 1) Notitia dignitatum: accedunt notitia urbis Constantinopolitanae et laterculi prouinciarium, ed. O. Seeck, Berolini 1876 (w zakresie ikonograficznym bazujący na rękopisie Monacensis Latinus 10291 (dawniej Palatinus 291) - Monachium, Bayerische Staatsbibliothek, Ms Clm 10291 (Sammelhandschrift), data powstania: 1542 i 1550-1551; wielkość folium: 310 x $240 \mathrm{~mm}$; fol. $88^{\mathrm{r}}-169^{\mathrm{v}}$ : tekst i miniatury; fol. 178 ${ }^{\mathrm{r}}-222^{\mathrm{r}}$ : miniatury); 2) La „, Notitia dignitatum ": nueva edición crítica y comentario histórico, [ed.] C. Neira Faleiro, Nueva Roma 25, Madrid 2005 (bazująca w zakresie iluminacji na rękopisie Oxoniensis Canonicianus Misc 378 - Oksford, Bodleian Library, western Ms 19854, fol. 88v-170r, data powstania: 1436, wielkość folium: 275 x 197 $\mathrm{mm}$ ); 3) Korzystano również z edycji elektronicznej: Notitia dignitatum (Monacensis Latinus 10291) pod adresem: http://daten.digitale-sammlungen.de/ db/bsb00005863/images/ [dostęp: 9 I 2018]. Ze względu na korzystanie $\mathrm{z}$ różnych rękopisów wnioski zawarte w niniejszych artykule odbiegają w szczegółach od spostrzeżeń Pameli C. Berger, The Insignia of the „Notitia dignitatum”. A Contribution to the Study of the Late Antique Illustrated Manuscripts, New York - London 1981.

${ }^{2}$ Zestawienie bogatej literatury na temat Notitia dignitatum por. http://notitiadignitatum.org/. Datowanie jej ostatecznej redakcji budzi wątpliwości w nauce i przyjąć należy, iż powstała na początku V w., a wyszła z oficjalnego użycia po 430 r., kiedy trafiła prawdopodobnie w ręce prywatne i to ta właśnie wersja była podstawą późniejszej kopii z czasów karolińskich. Część wschodnia wykazu sporządzona została w latach 394-395, z niewielkimi uzupełnieniami dodanymi w okresie późniejszym, najdalej w latach 406-408. Z kolei ostatnie korekty części zachodniej pochodzą z roku 419 lub 425. Na temat trudności w analizie tekstu tego źródła i jego charakteru, zob. J.H. Ward, The Notitia Dignitatum, „Latomus” 33 (1974) 397-434; P. Brennan, The „Notitia Dignitatum”, w: Les littératures techniques dans l'antiquité romaine. Statut, public et destination, tradition. Sept exposés suivis de discussions, Vandœuvres-Genève, 21-26 aoû 1995, éd. par C. Nicolet, Entretiens sur l'Antiquité Classique 42, Genève 1996, 147-178; tenże, The user's guide to the Notitia Dignitatum: the case of the Dux Armeniae (ND Or. 38), „Antichthon” 32 (1998) 34-49; M. Kulikowski, The „Notitia Dognitatum” as a Historical Source, „Historia” 49 (2000) 358-377; F. Millar, Greek Roman Empire. 
oraz - w wypadku dowódców wojskowych - podległe im jednostki wojskowe. Według współczesnego stanu wiedzy wszystkie znane wersje spisu są kopią Codex Spirensis z czasów karolińskich, który został sporządzony w oparciu o późnoantyczny oryginał z V w. (Codex Spirensis, który zaginął przed rokiem 1672).

Fragmenty tekstu dotyczącego urzędników cesarskich uzupełnione są w zachowanych dziś manuskryptach Notitia dignitatum - poza kilkoma wyjątkami - o karty z ilustracjami przedstawiającymi ich insygnia o zróżnicowanej w niewielkim stopniu wielkości. Ich zgodność z antycznym archetypem jest niekwestionowana ${ }^{3}$. W górnej części iluminacji zapisano tytuły dygnitarzy (minuskułą lub majuskułą w zależności od rękopisów) - il. 1a-b. Oryginalne insygnia władzy urzędników umieszczano przypuszczalnie w pomieszczeniach, gdzie dygnitarz pełnił czynności urzędowe ${ }^{4}$. Prezentują one kompetencje poszczególnych urzędników i ich pozycję w ramach administracji imperium późnorzymskiego oraz charakterystycznego dla niego systemu rang honorowych.

Ze względu na większą wiarygodność i dokładność informacji podawanej przez tekst Notitia dignitatum in partibus Orientis zdecydowałem się

Power and Belief under Theodosius II (408-450), Berkeley - Los Angeles - London 2006, 5-7. Por. A. Szopa, Notitia Dignitatum - ,najbardziej rzymski z dokumentów”?, „Annales Universitatis Paedagogicae Cracoviensis. Studia Historica” 8 (2009) 183-191; oraz obszerny wykaz literatury i przegląd stanowisk na ten temat: J. Wiewiorowski, Stanowisko prawne rzymskich dowódców wojsk prowincjonalnych-duces - w prowincjach Scythia Minor i Moesia Secunda, Poznań 2007, 23, nota 68.

${ }^{3}$ Przedmiotem licznych polemik jest sposób pracy iluminatorów, por. Berger, The Insignia, s. 142-167. Zob. I.C. Maier, The Barberinus and Munich Codices of the „Notitia Dignitatum omnium”, „Latomus” 28 (1969) nr 4, 960-1035, spec. s. 1024-1031; R. Grigg, Illustrations and Text in the lost Codex Spirensis, „Latomus” 46 (1987) nr 1, 204-210; J.J.G. Alexander, The illustrated manuscripts of the Notitia Dignitatum, w: tenże, Studies in Italian manuscript illumination, London 2002, 65-98; W. Seibt, Notitia dignitatum, w: Reallexikon zur byzantinischen Kunst, vol. 7, hrsg. von K. Wessel - M. Restle, Stuttgart 2004, 1030-1046; Ch. Kelly, Notitia dignitatum, w: The Classical Tradition, ed. by A. Grafton - G.W. Most - S. Settis, Cambridge Mass. - London 2010, 640-641.

${ }^{4} \mathrm{Na}$ temat insygniów, których oficjalny charakter jest niekiedy kwestionowany por. E. Polaschek, Notitia dignitatum, RE XVII/1, 1077-1116, spec. s. 1102-1109; R. Grigg, Portrait-Bearing Codicils in the Illustration of the „Notitia Dignitatum”?, JRS 59 (1979) 107-124; Berger, The Insignia, passim; R. Scharf, Comites und comitiva primi ordinis, Mainz 1994, 38-55; I. Gencheva-Mikami, Personification in impersonal context: late Roman bureaucracy and the illustrated Notitia dignitatum, w: Personification in the Greek world: from antiquity to Byzantium, ed. by E. Stafford - J. Herrin, Ashgate 2005, 285-291; Neira Faleiro, La „Notitia Dignitatum”, s. 32, 35-36 i 497-582 (szczegółowe uwagi w stosunku do poszczególnych rozdziałów z obszernymi wypisami z wcześniejszych edycji krytycznych); B.M. di Dario, La Notitia Dignitatum. Immagini e symboli del Tardo Impero Romano, Padova 2006, 7-20, 33. Por. też interpretacja insygniów jednej z grup dygnitarzy cesarskich: J. Wiewiorowski, Insignia of Roman Vicars of Dioceses as Representatives of divine emperors, „Signa Iuris” 10 (2012) 59-80; tenże, Sadownictwo późnorzymskich wikariuszy diecezji, Poznań 2012, 228-247 = The Judiciary of Diocesan Vicars in the Later Roman Empire, Poznań 2015, 236-256 (ze względu na wprowadzone w wydaniu anglojęzycznym zmiany cytuję niżej późniejsze wydanie). Wiarygodność niektórych innych elementów graficznych w Notitia dignitatum jest niekiedy podważana, por. R. Grigg, Inconsistency and Lassitude: The Shield Emblems of the Notitia Dignitatum, JRS 73 (1983) 132-142. 
w niniejszym artykule poddać analizie insygnia tylko tej części listy, i to tylko te, z którymi miałem okazję zapoznać się bliżej podczas wcześniejszych studiów ${ }^{5}$. Wykorzystałem w analizie dwa najważniejsze manuskrypty Notitia dignitatum. Pierwszym był XV-wieczny rękopis Oxoniensis z 1436 r., w którym twórcą iluminacji był przypuszczalnie pochodzący z Francji Péronet Lamy ${ }^{6}$. Autor iluminacji w Monacensis Latinus, drugim z uwzględnionych rękopisów, jest anonimowy. Spis ten uchodzi za najbardziej wiarygodny w zakresie przekazu ikonograficznego, jakkolwiek sporządzony został w połowie XVI wie$\mathrm{ku}^{7}$. W porządku analizy zachowano kolejność przyjętą w Notitia dignitatum.

Notitia dignitatum in partibus Orientis posiada siedem (lub ewentualnie osiem) wyobrażeń insygniów zawierających bezpośrednie odnośniki do rzeczywistości geograficznej (Notitia dignitatum in partibus Orientis 28-29, 31, 34 i 3639). Były to insygnia regionalnych dowódców wojskowych, tj. comites i duces ${ }^{8}$, w przypadku których wyobrażenia zawierają symboliczne mapy ${ }^{9}$. Forma „mapy” charakterystyczna była dla insygniów dowódców armii tego szczebla także w Notitia dignitatum in partibus Occidentis (jedynym wyjątkiem są insygnia vicarius Britanniarum, które również uwzględniają „mape”), aczkolwiek wyobrażenia te $\mathrm{w}$ mniejszym stopniu korespondowały z realiami geograficznymi ${ }^{10}$. Dodatkowo przemawia to za skupieniem uwagi na wschodniej części spisu.

${ }^{5}$ Por. J. Wiewiorowski, Szczegóły geograficzne w Notitia dignitatum in partibus Orientis, „U schyłku starożytności - Studia Źródłoznawcze” 12 (2013) 149-181. Niniejszy tekst rozwija część przedstawionych tam uwag. Na temat dokładności tekstu Notitia dignitatum in partibus Orientis, zob. B. Salway, Putting the world in order: mapping in Roman texts, w: Ancient Perspectives: Maps and Their Place in Mesopotamia, Egypt, Greece, and Rome, ed. by R.J.A. Talbert, Chicago 2012, 193-234, spec. s. 202.

${ }^{6}$ Perenet lenlumineur - „Péronet iluminator”, działający od 1432 r., zmarły przed lipcem 1453 r. Por. Sh. Edmunds, The Missals of Felix V and Early Savoyard Illumination, „The Art Bulletin” 46 (1964) nr 2, 127-141. Por. też https://en.wikipedia.org/wiki/Peronet_Lamy [dostęp: 10 I 2018].

${ }^{7}$ Por. R. O'Hara, An Assessment of the Notitia Dignitatum as a Historical Source for the Late Roman Bureaucracy, Maynooth 2013, 30-34 - ta rozprawa doktorska jest dostępna pod adresem: http://eprints.maynoothuniversity.ie/4593/ [dostęp: 10 I 2018].

${ }^{8}$ Por. Wiewiorowski, Stanowisko prawne, passim; tenże, Duces Scythiae Minoris. A Prosopographical Study, Poznań 2008, 11-17 - na przykładzie duces Moesiae secundae i Scythiae Minoris (tutaj znajduje się też literatura przedmiotu).

${ }^{9} \mathrm{Na}$ temat symbolicznego a zarazem dydaktycznego charakteru map w insygniach Notitia dignitatum (oraz samego tekstu spisu) por. O.A.W. Dilke, Itineraries and Geographical Maps in the Early and Late Roman Empires, w: The History of Cartography, vol. 1. Cartography in prehistoric, ancient, and medieval Europe and the Mediterranean, ed. by J.B. Harley - D. Woodward, Chicago 1987, 244-245; G. Traina, Mapping the world under Theodosius II, w: Theodosius II: Rethinking the Roman Empire in Late Antiquity, ed. by Ch. Kelly, Cambridge 2013, 155-171.

${ }^{10}$ Szczegóły geograficzne dostrzec można ewentualnie w przypadku Notitia dignitatum in partibus Occidentis 23: vicarius Britanniarum; 26: Comes litoris saxonici per Britanniam; 27: Comes Britanniae; 28: Comes Italiae (adekwatność tego wyobrażenia jest jednak kwestionowana, por. P. Kos, Barriers in the Julian Alps and Notitia Dignitatum, „Acta Archaeologica” 65 (2014) 409-422); 29: Comes Argentoratensis; 40: Dux Britanniarum. Por. zwłaszcza Berger, The Insignia, s. 111-124. Podobieństwo insygniów wikariusza Brytanii do insygniów dowódców wojskowych 
Współcześnie mapy najczęściej orientowane są na północ, podczas, gdy w antyku stosowano często też orientację południową, i taka sama niejednolitość występuje w Notitia dignitatum ${ }^{11}$. Kolory tła „map” są w nich różnorodne, a w manuskrypcie Oxoniensis różnicowane są jego odcienie, a ponadto i narysowano dodatkowe kreski, co sprawia wrażenie, że mają one wyobrażać grunt. Zazwyczaj wyodrębniony jest w nich górny pas, błękitny w przypadku rękopisu Oxoniensis, co wzmacnia iluzję, że mamy do czynienia z warstwą atmosfery ziemskiej. Na tym tle przedstawione są umocnienia o różnorodnej kolorystyce i rozmiarach, które, jak powszechnie przyjmuje się w literaturze, są uproszczoną wersją znanych z innych źródeł wyobrażeń fortów (castella) lub wież strażniczych, z nazwami zapisanymi minuskułą (w rękopisie Oxoniensis umieszczono je w białych winietach ponad fortami, a same ich wyobrażenia nawiązują do form architektury gotyckiej) - il. $1 b^{12}$.

W lewym górnym rogu „map” zamieszczono prostokąty, najczęściej czerwone (tylko w przypadku dux provinciae Sequanicae prostokąt jest koloru niebieskiego: Notitia dignitatum in partibus Occidentis 36), z wyobrażeniami zwoju (w kolorze białym lub żółtym) i księgi (przeważnie w różnych ocieniach koloru żółtego). Księgi opatrzone są napisami o treści Fl/intall/comord/PR, który podkreślał przynależność dowódców do comites primi ordinis, tj. spectabiles ${ }^{13}$. Zwoje najprawdopo-

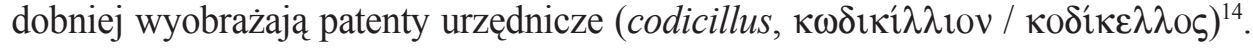

prowadzi do wysuwania sugestii, iż miał on pewne kompetencje wojskowe, por. Wiewiorowski, Insignia, s. 67; tenże, The Judiciary, s. 253-256.

${ }^{11}$ Por. R.J.A. Talbert, Rome's world: the Peutinger map reconsidered, New York 2010, 96-97.

${ }^{12}$ Por. Berger, The Insignia, s. 113-114.

${ }^{13}$ Jeśli chodzi o próby jego rozszyfrowania podawane w literaturze przedmiotu, por. O. Seeck, Codicilli 5, RE IV 180. Za nim poszli: Grigg, Portrait-Bearing Codicils, s. 115: „Feliciter! inter allectos comes primi ordinis”; R. Delbrück, Die Consulardiptychen und verwandte Denkmäler, Bd. 1: Text, Studien zur Spätantiken Kunstgeschichte 2/1, Berlin - Leipzig 1929, 255. Z kolei za nimi szli: Polaschek, Notitia, s. 1108 oraz Berger, The Insignia, s. 108: „Floreas/ inter/ allectos/ comites/ ordinis primi”; Scharf, Comites, s. 39: „Fl(oreas) int(er) ali(is) com(ites) ord(inis) pr(imi)”; Neira Faleiro, La „Notitia Dignitatum”, s. 32, nota 16: „Floreas [lub] Feliciter/ inter/ allectos/ comites/ primi/ ordinis". Por. też V. Marotta, Mandata Principum, Torino 1991, 12, nota 31; R. Scharf, Der Dux Mogontiacensis und die Notitia Dignitatum. Eine Studie zur spätantiken Grenzverteidigung, Berlin - New York 2005, 72-75. Taką samą inskrypcję zawierają wyobrażenia insygniów vicarii (pars Orientis) i primicerius notarii, castrensis i vicarii (pars Occidentis). Na temat comites primi ordinis z nowszych prac zob. G. de Bonfils, Il comes et quaestor nell'età della dinastia costantiniana, Napoli 1981, 1-39; Scharf, Comites, passim.

${ }^{14} \mathrm{Na}$ temat patentów urzędniczych zob. O. Karlowa, Römische Rechtsgeschichte, vol. 1, Leipzig 1885, 869-871; Seeck, Codicilli 5, passim (w swojej edycji Notitia dignitatitum, na s. 23 i 31 sugerował, że zwoje to libri mandatorum); Polaschek, Notitia, s. 1106-1107; A. Chastagnol, La préfecture urbaine à Rome sous le Bas-Empire, Paris 1960, 196-203; F. Dölger - J. Karayannopulos, Byzantinische Urkundenlehre, München 1968, 113-115; Grigg, Portrait-Bearing Codicils, s. 112-118; Berger, The Insignia, s. 103-105 i 175-183; Scharf, Comites, s. 46-47; J. Engemann, Herrscherbild, RACh XIV 1020-1022; Neira Faleiro, La „Notitia Dignitatum”, s. 31-32 i 506-507. Znaki pisarskie utrwalone na brzegach zwojów w niektórych insygniach są zniekształconymi literami greckiego alfabetu, co świadczyć ma o nikłym stopniu znajomości greki na Zachodzie w czasach, 
Z kolei codices większość badaczy uznaje za wyobrażenia libri mandatorum (ksiag instrukcji cesarskich) - il. 1a-b ${ }^{15}$.

Więcej odrębności występuje w przypadku comes limitis Aegypti i comes per Isauriam (Notitia dignitatum in partibus Orientis 28 i 29 - il. 1a-b oraz il. 2a-b). W przypadku ich insygniów wyobrażenia zwojów i kodeksów spoczywają na jasnobrązowych stołach, przykrytych udrapowaną niebieską tkanina, które umiejscowiono w górnych fragmentach ilustracji. Podobne wyobrażenia stołów zawierają też ilustracje insygniów większości wyższych urzędników cesarskich w obu częściach Notitia dignitatum ${ }^{16}$. Stoły symbolizują przypuszczalnie sądownicze i administracyjne uprawnienia urzędników cesarskich ${ }^{17}$.

gdy powstawały zachowane do dzisiaj rękopisy Notitia dignitatum (Notitia dignitatum in partis Orientis 33, 36, 38 i 39 według rękopisu Monacensis Latinus), por. Berger, The Insignia, s. 124. Na temat znajomości greki na Zachodzie zob. W. Berschin, Grecko-łacińskie średniowiecze. Od Hieronima do Mikołaja z Kuzy, thum. K. Liman, Gniezno 2003, 40-74.

${ }^{15}$ Por. W.C. Loerke, The Miniatures of the Trial in the Rossano Gospels, „The Art Bulletin” 43 (1961) nr 2, 177-178; Berger, The Insignia, s. 107-108, 123-125 i 191-197; Marotta, Mandata, s. 7173; Gencheva-Mikami, Personification, s. 287. Wedhug Roberta Grigga (Portrait-Bearing Codicils, s. 110 i 118-119), księgi to patenty nominacyjne. Por. też Scharf, Comites, s. 49, nota 125, który zasadnie zdystansował się od tego poglądu oraz polemizował z Pamelą C. Berger (The Insignia), ostatecznie nie formułując jednak własnej opinii. Z kolei dla Concepción Neira Faleiro (La „Notitia Dignitatum”, s. 32, 507 i 511-512) codices to libri mandatorum, podczas, gdy zwoje przedstawiać miały mandata privatae imperatoris, a oba wyobrażenia łącznie symbolizowały jej zdaniem patent urzędniczy.

${ }^{16}$ Poza primicerius notariorum, magister scriniorum, vicarius Britanniarum i pozostałymi regionalnymi dowódcami wojskowymi - comites rei militaris i duces, por. Notitia dignitatum in partibus Orientis 18, 19 i 31-42; Notitia dignitatum in partibus Occidentis 16, 17 i 23-41.

${ }^{17} \mathrm{Nie}$ oznaczają one natomiast przynależności do comites primi ordinis. Por. Berger, The Insignia, s. 106-109, 121-124 i 196-197. Inny pogląd wyraził Ralf Scharf (Comites, s. 44-45): według niego stół mógł być symbolem rangi, który wyszedł z użycia przed połową IV w. Obecność stołów na ilustracjach insygniów comites limitis Aegypti i per Isauriam podkreśla znaczenie ich kompetencji w przypadku obu dowódców wojskowych. Comes limitis Aegypti przypuszczalnie miał pewne kompetencje w sprawach administracji cywilnej, tak jak z pewnością posiadał je jego następca w 2. poł. V w.: dux lub comes (Aegyptiaci limitis) et praefectus Augustalis. Por. R.M. Price, The limes of Lower Egypt, w: Aspects of the Notitia Dignitatum, ed. by R. Goodburn - R. Bartholemew, British Archaeological Reports. Supplementary Series 15, Oxford 1976, 146-151; J.-M. Carrié, Séparation ou cumul? Pouvoir civil et autorité militaire dans les provinces d'Égypte de Gallien à la conquête arabe, „Antiquité Tardive” 6 (1998) 105-121, spec. s. 109-110); B. Palme, The imperial presence: Government and army, w: Egypt in the Byzantine World, 300-700, ed. by R.S. Bagnal, Cambridge 2007, 240-270. Comes Isauriae z pewnością łączył funkcje dowódcy wojskowego i cywilnego namiestnika prowincji do ok. 491-498 oraz po 536 r., por. B.D. Shaw, Bandit Highlands and Lowland Peace: The Mountains of Isauria-Cilicia, ,Journal of the Economic and Social History of the Orient” 33 (1990) 227-239; W.D. Burgess Jr., Isauria and the Notitia Dignitatum, „The Ancient World” 26 (1995) nr 1, 79-88; N. Lenski, Assimilation and Revolt in the Territory of Isauria, From the 1st Century BC to the 6th Century AD, ,Journal of the Economic and Social History of the Orient” 42 (1999) 413-465; H. Elton, The Nature of the Sixth-century Isaurians, w: Ethnicity and Culture in Late Antiquity, ed. by S. Mitchell - G. Greatrex, London 2000, 293-307; K. Feld, Barbarische Bürger. Die Isaurier und das Römische Reich, Berlin - New York 2005, 87-101 i 138-340. Por. też R. Kosiński, Izauria w orbicie wpływów rzymskich do połowy V wieku, „Białostockie Teki Historyczne” 8 (2010) 11-26. Twórcy 
Przejdźmy teraz do tzw. szczegółów geograficznych. Wyobrażenie insygniów comes limitis Aegypti zawiera w górnej części pas (Oxoniensis - niebieski; Monacensis Latinus - ciemnobrązowy). W środkowej części widnieje przedstawienie Fl[umen] Nilus w kolorze niebieskim (z nazwą zapisaną w tle, które „faluje” na rękopisie Oxoniensis), zorientowane od lewego górnego do prawego dolnego brzegu ilustracji oraz różnokolorowych dziewięć miejsc umocnionych na tle w kolorze jasnobrązowym/beżowym, o różnych odcieniach i z kreskami (w przypadku Oxoniensis) lub jasno-ciemnobrązowym (Monacensis Latinus), z wyobrażeniem piramid opatrzonych napisem Pyramides (Notitia dignitatum in partibus Orientis 28 - il. 1a-b). Nazwy te odpowiadaja grosso modo nazwom miejsc stacjonowania części oddziałów wojskowych, podporządkowanych comes limitis Aegypti według tekstu Notitia dignitatum (przedstawiono tylko najważniejsze castella). Zróżnicowane kształtem signa jednostek wojskowych stacjonujących w poszczególnych fortach zbliżone są formą do ich wyobrażeń znanych z innych źródeł (bardziej realistyczne są w przypadku rękopisu Oxoniensis) ${ }^{18}$. Na „mapie” widać też w centralnej części wyobrażenie bliżej nieokreślonego zwierzęcia w kolorze brązowym (z otwartą paszczą według Monacensis Latinus).

Jak miałem już okazję zauważyć w innym miejscu, poza poprawnym umiejscowieniem piramid oraz nazwami miejsc umocnionych, „mapa” w insigniach

iluminacji nie byli jednak konsekwentni, gdyż dux et praeses Arabiae i dux et praeses Mauretaniae, którzy z pewnością byli równocześnie dowódcami wojskowymi i namiestnikami prowincji, posiadać mieli według Notitia dignitatum insygnia analogiczne jak ,zwykli” dowódcy wojskowi (Notitia dignitatum in partibus Orientis 37; Notitia dignitatum in partibus Occidentis 30).

${ }^{18}$ Forty uszeregowane są w grupach. Pierwszą, licząc od górnego lewego rogu, zajmują: $B a$ bylonia (według Monacensis Latinus umiejscowiona jest ona na ciemnobrązowym górnym pasie), Memfi, Pelusio i Thamudena. Między dwoma ostatnimi dostrzec można wyobrażenie piramid, a kolejny fort, Andros umiejscowiony jest poniżej. W dolnej części insygniów znajdują się Archadiana, Parembole i Theodosiana (w jednej linii) oraz Oasi minor. Por. Notitia dignitatum in partibus Orientis 28, 13-53, ed. O. Seeck, s. 59-60: „Sub dispositione viri spectabilis comitis rei militaris per Aegyptum: Legio quinta Macedonica, Memfi. Legio tertiadecima gemina, Babilona. Equites stablesiani, Pelusio. Equites Saraceni Thamudeni, Scenas Ueteranorum. Legio tertia Diocletiana [Thebaidos], Andro. Legio secunda Traiana, Parembole. Ala Theodosiana nuper constituta. Ala Arcadiana nuper constituta. Ala secunda Armeniorum, Oasi minore. Et quae de minore laterculo emittuntur: Ala tertia Arabum, Thenenuthi. Ala octaua Uandilorum, Nee. Ala septima Sarmatarum, Scenas Mandrorum. Ala prima Aegyptiorum, Selle. Ala ueterana Gallorum, Rinocoruna. Ala prima Herculia, Scenas extra Gerasa. Ala quinta Raetorum, Scenas Ueteranorum. Ala prima Tingitana, Thinunepsi. Ala Apriana, Hipponos. Ala secunda Assyriorum, Sosteos. Ala quinta Praelectorum, Dionisiada. Cohors tertia Galatarum, Cefro. Cohors secunda Astarum, Busiris. Provinciae Augustamnicae: Ala secunda Ulpia Afrorum, Thaubasteos. Ala secunda Aegyptiorum, Tacasiria. Cohors prima sagittariorum, Naithu. Cohors prima Augusta Pannoniorum, Tohu. Cohors prima Epireorum, Castra Iudaeorum. Cohors quarta Iuthungorum, Affrodito. Cohors secunda Ituraeorum, Aiy. Cohors secunda Thracum, Muson. Cohors quarta Numidarum, Narmunthi. Officium autem habet ita: Principem de scola agentum in rebus ducenarium, qui adorata clementia principali cum insignibus exit. Numerarios. Commentariensem. Adiutorem. A libellis siue subscribendarium. Exceptores et ceteros officiales". Por. Berger, The Insignia, s. 121-123. 
comes limitis Aegypti nie odpowiada realiom geograficznym - il. $3^{19}$. Kolorystyka szczegółów geograficznych jest jednak w miarę realistyczna: wyobrażenie Nilu jest koloru niebieskiego, grunt na których umieszczono forty ma kolor „ziemisty”. Wyobrażenie zwierzęcia przypomina niedźwiedzia. Jest ono przedstawione, tak jak dobrze znane Rzymianom (i ludziom średniowiecza) zwierzęta, jako stworzenie posiadające umaszczenie brunatne (co mocniej uwypuklił iluminator Monacensis Latinus - il. 1a i 4) ${ }^{20}$. Możliwa jest jednak inna, bardziej prawdopodobna interpretacja, zgodnie z którą w iluminacji Notitia dignitatum in partibus Orientis 28 nieudolnie przedstawiono hipopotama nilowego (Hippopotamus amphibius). Zwierzę to kojarzono w starożytności z Egiptem, lecz było ono słabo znane Rzymianom i w ogóle Europejczykom, aż do czasów nowożytnych ${ }^{21}$. Świadczą o tym też zachowane jego wyobrażenia, w których prezentowano umaszczenie hipopotamów jako brązowe i eksponowano, zgodnie z rzeczywistościa, agresywne zachowania tych zwierząt, wyrażające się w m.in. w otwieraniu pyska, obnażającym potężne kły, co dobrze ilustruje Monacensis Latinus - il. 5a-b22. Przyjmując utożsamienie zwierzęcia z Notitia dignitatum in partibus Orientis $28 \mathrm{z}$ hipopotamem, także

${ }^{19}$ Por. Barrington Atlas of the Greek and Roman World, ed. by R. Talbert, Princeton - Oxford 2000, pl. 74-75. Zob. Price, The limes of Lower Egypt, s. 143-156; Dilke, Itineraries and Geographical Maps, s. 245; K.A. Worp, Observations on Some Military Camps and Place Names in Lower Egypt, ZPE 87 (1991) 291-295.

${ }^{20}$ Starożytni nie zetknęli się najprawdopodobniej bezpośrednio z niedźwiedziami polarnymi (Ursus maritimus), chociaż nie można wykluczyć, że znali ich wypreparowane skóry (słusznie zasugerował to prof. Marek Wilczyński, Katedra Historii Starożytnej, Uniwersytet Pedagogiczny im. KEN w Krakowie). Por. G. Jennison, Animals for Show and Pleasure in Ancient Rome, Manchester 1937, 34, 71 i 189; B. Baldwin, Better Late and Early: Reflections on the Date of Calpurnius Siculus, „Illinois Classical Studies” 20 (1995) 157-167. W tym kontekście można wskazać, że Ursus arctos crowtheri, wymarły podgatunek niedźwiedzia brunatnego, żył w Afryce północnej (w górach Atlas i w Maroku) co najmniej do V w. po Chr. Osobniki tego podgatunku niedźwiedzia brunatnego wykorzystywano też podczas igrzysk cyrkowych, organizowanych niekiedy w Egipcie. Por. Z. Kádár, Some zoogeographical aspects of the NW African vertebrate fauna in historical times: archeological and cultural historical methods in the research, „Vertebrata Hungarica” 18 (1978) 79-83; S. Calvignac [et al.], Ancient DNA evidence for the loss of a highly divergent brown bear clade during historical times, „Molecular Ecology” 17 (2008) 1962-1970; M. MacKinnon, Supplying Exotic Animals for the Roman Amphitheatre Games: New Reconstructions Combining Archaeological, Ancient Textual, Historical and Ethnographic Data, „Mouseion” 6 (2006) 137-161. Na temat niedźwiedzia w kulturze rzymskiej zob. J.M.C. Toynbee, Animals in Roman Life and Art, London 1973, 93-100. Damnatio ad bestias nie została zniesiona, wbrew rozpowszechnionym opiniom w czasach konstantyńskich, ale być może dopiero za Anastazjusza I (około 493 r.?). Konstantyn I nie zniósł też całkowicie damnatio ad ludum gladiatorum, która to kara stosowana była co najmniej do połowy V w. Por. F. Carlá - M.G. Castello, Questioni tardoantichi. Storia e mito della ,svolta constantiniana”, Roma 2010, 264-319.

${ }^{21}$ Por. G. Malinowski, Zwierzęta świata antycznego. Studia nad „, Geografia” Strabona, Wrocław 2003, 137-139. Za tę sugestię dziękuję dr Benetowi Salwayowi (Department of History, University College London).

${ }^{22}$ Por. Jennison, Animals for Show, s. 50-51, 66 i 147; Toynbee, Animals, s. 128-130; G. Malinowski, Źródła do Pliniuszowego opisu zwierzęcia zwanego eale (Naturalis Historia VIII 73), „Acta 
i w tym przypadku iluminatorzy starali się (zwłaszcza anonimowy twórca ilustracji w Monacensis Latinus) oddać w miarę realistycznie umaszczenie, sylwetkę i charakterystyczne zachowania Hippopotamus amphibius.

Przyjrzyjmy się teraz ilustracji insygniów comes per Isauriam (Notitia dignitatum in partibus Orientis 29 - il. 2a-b). Górny pas opatrzony napisem Mare jest niebieski w rękopisie Oxoniensis, a ciemnobrązowy w Monacensis Latinus. Nienazwanych pięć fortów umiejscowiono w dolnej części ilustracji, poniżej skalistych wierzchołków górskich w kolorze brązowym, co podkreślił Péronet Lamy, iluminator Oxoniensis, za pomocą dodatkowych kresek i z wykorzystaniem odcieni koloru jasnobrązowego oraz poprzez napis Mons Taurus (Góry Taurus), zajmujący centralną część „mapy” od lewego dolnego do prawego górnego jej brzegu ${ }^{23}$. Dwa większe miejsca umocnione przedstawiono poniżej „gór" na innym tle (zielonym w manuskrypcie Oxoniensis; żołtawym w Monacensis Latinus). Jeden większy fort położony jest w tle koloru żółtego (opisany jako Tharsus), niedaleko pasa innego koloru (niebieskiego w rękopisie Oxoniensis, w który nazwa Tarsium mare ${ }^{24}$ widnieje w dwóch białych kartuszach; w rękopisie Monacensis Latinus kolor jest analogiczny jak w przypadku wyobrażenia gór i opatrzony jest napisem Mare). W środkowej części „gór” dostrzec można zarys tylnej części ciała ssaka (podobnego do kotowatych) w kolorze szarym, a pasący się rogaty jeleń w kolorze jasnobrązowym umiejscowiony jest w prawej dolnej części insygniów, poniżej wierzchołków „gór”.

Jak już zauważyłem onegdaj, wyobrażenie to koresponduje z tekstem Notitia dignitatum in partibus Orientis 29 , który pomija nazwy miejsc stacjonowania jednostek wojskowych podporządkowanych comes per Isauriam, a jego insygnia zasadniczo zgodnie prezentują topografię Izaurii - il. $6 \mathrm{a}^{25}$. Kolorystyka insygniów również nawiązuje do barw naturalnych przedstawionych obiektów $\mathrm{i}$ istot żywych: wyobrażenie części ciała kota koresponduje z umaszczeniem żyjącego w nich do najnowszych czasów podgatunku pantery (Panthera pardus tulliana), dobrze znanego starożytnym oraz pospolitego do dziś na terenie Azji Mniejszej i Eurazji jelenia szlachetnego (Cervus elaphus) - il. 6b-c ${ }^{26}$. Większą wierność realiom środowiska naturalnego Izaurii zachował przy tym

Universitatis Wratislaviensis. Classica Wratislaviensia” 20 (1996) 101-107; MacKinnon, Supplying Exotic Animals, s. 5.

${ }^{23} \mathrm{Na}$ temat sposobu wyobrażeń innych gór, Alp Julijskich, w ilustracjach Notitia dignitatum por. też Kos, Barriers, passim.

${ }^{24}$ Nazwa nawiązuje do miasta Tarsus, położonego w południowej Anatolii, około $20 \mathrm{~km}$ od wybrzeża Morza Śródziemnego, por. Barrington Atlas, pl. 66. Na temat jego dziejów w czasach rzymskich zob. A.H.M. Jones, The Cities of the Eastern Roman Provinces, Oxford 197122, 191-214.

${ }^{25}$ Por. Wiewiorowski, Szczegóty, s. 159. Zob. Notitia dignitatum in partibus Orientis 29, 6-17, ed. Seeck, s. 61-62: „Sub dispositione uiri spectabilis comitis rei militaris per Isauriam et praesidis: Legio secunda Isaura. Legio tertia Isaura. Officium autem habet ita: Principem de eodem officio. Cornicularium. Commentariensem. Numerarios. Adiutorem. Ab actis. A libellis. Exceptores et ceteros officiales".

${ }^{26} \mathrm{Na}$ temat pantery w kulturze rzymskiej por. Jennison, Animals for Show, s. 183-187; Toynbee, Animals, s. 143-147; Malinowski, Zwierzęta, s. 108-110. 
iluminator Péronet Lamy, twórca ilustracji w rękopisie Oxonienis. Z kolei wyobrażenia jelenia i ,pantery” z większym pietyzmem oddał iluminator Monacensis Latinus - il. 2a-b.

„Mapa” w ilustracji insygniów egipskiego dux Thebaidos w rękopisie Oxoniensis od góry ma jasnoniebieski pas. W obu analizowanych manuskryptach w centrum widnieje wstęga w kolorze niebieskim, z napisem Fl[umen] Nilus, przecinająca jasnobrązowe tło o różnych odcieniach i z dodatkowymi kreskami (Oxoniensis) lub też tło jasnoróżowe (Monacensis Latinus): Notitia dignitatum in partibus Orientis 31 - il. 7a-b. Rzeka płynie trzema korytami łączącymi się w górnym rogu, a osiemnaście fortów wyobrażonych jest w porządku od góry do dołu ${ }^{27}$. Jedno castellum (Filari) umieszczone zostało w nurcie „rzeki”. Z kolei fort Diospolis znajduje się na wyspie, a fort Ambos został usytuowany na trójkątnym obszarze pomiędzy dwoma ramionami Nilu ${ }^{28}$.

Jak już miałem okazję uzasadniać wcześniej, wyobrażenie to nie odpowiada rzeczywistości, ponieważ koryto Nilu nie dzieli się na odnogi na terytorium Górnego Egiptu. Natomiast nazwy punktów umocnionych odpowiadają tylko w części nazwom miejsc stacjonowania oddziałów wojskowych podporządkowanych duksowi Thebaidy według Notitia dignitatum. Rzeczywiste usytuowanie geograficzne punktów umocnionych było odmienne, za wyjątkiem castellum Filari, który to fort istotnie znajdował się na wyspie rzecznej Philae, a jej umiejscowienie na „mapie” wskazuje, iż „mapa” ta jest zorientowana na południe - il. $8^{29}$. Kolory zastosowane do wyobrażenia Nilu oraz terenów

${ }^{27}$ Sa to: Filari, Hermunthus, Hermipolis, Lato, Tentyra, Cusa, Oasis maior, Asfinis, Thebas, Apollonos, Syene, Presentia, Diospolis, Lyco, Copto, Copto, Ambos, Maximianopilis.

${ }^{28}$ Jak zasadnie zaznaczono w literaturze, egipski system obronny pod dowództwem $d u x$ Thebaidos oparty był na oddziałach w miarę regularnie rozmieszczonych w fortach, usytuowanych na przeciwległych brzegach Nilu. Por. K.A. Worp, The Notitia dignitatum and the geography of Egypt: observations on some military camps and place names in Upper Egypt, w: Proceedings of the 20th international congress of papyrologists, Copenhagen, 23-29 August, 1992, ed. by A. Bülow-Jacobsen, Copenhagen 1994, 467.

${ }^{29}$ Por. Wiewiorowski, Szczegóty, s. 159-160. Zob. Notitia dignitatum in partibus Orientis 31, 22-74, ed. Seeck, s. 64-66: „Sub dispositione uiri spectabilis ducis Thebaidos: Cuneus equitum Maurorum scutariorum, Lico. Cuneus equitum scutariorum, Hermupoli. Equites sagittarii indigenae, Tentira. Equites sagittarii indigenae, Copto. Equites sagittarii indigenae, Diospoli. Equites sagittarii indigenae, Lato. Equites sagittarii indigenae, Maximianopoli. Equites promoti indigenae [...]. Legio tertia Diocletiana, Ombos. Legio secunda Flauia Constantia Thebaeorum, Cusas. Legio tertia Diocletiana, Praesentia. Legio secunda Traiana, Apollonos superioris. Milites Miliarenses, Syene. Legio prima Valentiniana, Copto. Legio prima Maximiana, Filas. Legio tertia Diocletiana, Thebas. Legio secunda Valentiniana, Hermunthi. Equites felices Honoriani, Asfynis. Ala prima Abasgorum, Hibeos - Oaseos maioris. Et quae de minore laterculo emittuntur: Ala secunda Hispanorum, Poisarietemidos. Ala Germanorum, Pescla. Ala quarta Britonum, Isiu. Ala prima Hiberorum, Thmou. Ala Neptunia, Chenoboscia. Ala tertia dromedariorum, Maximianopoli. Ala octaua Palmyrenorum, Foenicionis. Ala septima Herculia uoluntaria, contra Lata. Ala prima Francorum, contra Apollonos. Ala prima Iouia catafractariorum, Pampane. Ala octava [...], Abydum - Abocedo. Ala secunda Herculia dromedariorum, Psinaula. Ala prima Abasgorum, Oasi maiore. Ala prima Quadorum, 
wchodzących w skład dukatu są jednak realistyczne. Większy realizm zachował przy tym twórca iluminacji rękopisu Oxoniensis, Péronet Lamy.

„Mapa” w ilustracji insygniów dux Palaestinae w rękopisie Oxoniensis posiada biegnący od góry jasnoniebieski pas. We wszystkich manuskryptach przez „mapę" tę od góry do dołu łagodnie meandruje niebieska wstęga, z nazwą Fl[umen] Iordanis zapisaną w tle (Notitia dignitatum in partibus Orientis 34 - il. 9a-b) ${ }^{30}$. W rękopisie Oxoniensis górna część biegu „,rzeki” umieszczona została na tle niebieskim a reszta na tle brązowo-zielonym o zróżnicowanym odcieniu (z kreskami), podczas gdy według rękopisu Monacensis Latinus całe tło jest niebieskie. Na lewym brzegu Jordanu usytuowano schematyczne przedstawienia ośmiu fortów. Pierwszym od góry jest Menoida. Z kolei następne castella zostały połączone w pary i umieszczone w jednej linii. Są to: Zodocatha i Sabaia, Robatha i Hauare, Ueterocania i Mohaila. Poniżej ostatniego z nich, Mohaila, dostrzec można wyobrażenia dwóch stworzeń w kolorze jasnobrązowym, przypominających szczekających przedstawicieli psowatych (Canidae). Rękopis Oxoniensis zawiera również w dolnej prawej części zarys postaci szczekającego stworzenia w kolorze jasnobrązowym, $\mathrm{z}$ widocznymi dwoma przednimi nogami. Natomiast na prawym brzegu Jordanu znalazło się pięć fortów. Są to (od góry): Berosaba, Chermula, Zoara, Birsama i Aelia).

Jak już pisałem wcześniej w innym miejscu, ,mapa” w insygniach duksa Palestyny jest częściowo zgodna z realiami geograficznymi. Rzeka Jordan bowiem istotnie łagodnie meandruje przez terytorium Palestyny. Również nazwy fortów odpowiadają przynajmniej częściowo nazwom miejsc stacjonowania oddziałów wojskowych podporządkowanych dux Palaestinae według Notitia dignitatum, ale ich usytuowanie jest przypadkowe - il. $10 \mathrm{a}^{31}$. Także i w tym

Oasi minore - Trimtheos. Ala prima Ualeria dromedariorum, Precteos. Cohors prima Lusitanorum, Theraco. Cohors scutata ciuium Romanorum, Mutheos. Cohors prima Apamenorum, Silili. Cohors undecima Chamauorum, Peamu. Cohors nona Tzanorum, Nitnu. Cohors nona Alamannorum, Burgo Seueri. Cohors prima felix Theodosiana, apud Elephantinem. Cohors quinta Suentium [...], Suene. Cohors sexta saginarum, in Castris Lapidariorum. Cohors septima Francorum, Diospoli. Officium autem uiri spectabilis ducis Thebaidos habet ita: Principem de scola agentum in rebus. Numerarios et adiutores eorum. Adiutorem. Commentariensem. A libellis siue subscribendarium. Exceptores et ceteros officiales". Por. Barrington Atlas, pl. 77-80.

${ }^{30}$ Por. W.D. Ward, From Provincia Arabia to Palaestina Tertia: The Impact of Geography, Economy, and Religion on. Sedentary and Nomadic Communities in the Later Roman Province. of Third Palestine, Los Angeles 2008, 89-90. Na temat Palestyny w okresie późnoantycznym zob. H. Sivan, Palestine in Late Antiquity, Oxford 2008, passim.

${ }^{31}$ Por. Wiewiorowski, Szczegóły, s. 160-162. Zob. Notitia dignitatum in partibus Orientis 34, 17-55, ed. Seeck, s. 73-74: „Sub dispositione uiri spectabilis ducis Palaestinae: Equites Dalmatae Illyriciani, Benosabae. Equites promoti Illyriciani, Menochiae. Equites scutarii Illyriciani, Chermulae. Equites Mauri Illyriciani, Aeliae. Equites Thamudeni Illyriciani, Birsama. Equites promiti indigenae, Sabaiae. Equites promiti indigenae, Zodocathae. Equites sagittarii indigenae, Hauanae. Equites sagittarii indigenae, Zoarae. Equites sagittarii indigenae, Robatha. Equites primi felices [sagittarii indigenae] Palaestini, Sabure siue Ueterocariae. Equites sagittarii indigenae, Moahile. Praefectus legionis decimae Fretensis, Ailae. Et quae de minore laterculo emittuntur: Ala 
przypadku widać skłonność iluminatorów do kolorystyki w miarę realistycznie oddającej krajobraz dukatu (bliższy realiom był twórca iluminacji rękopisu Oxoniensis, Péronet Lamy) i umaszczenie zamieszkujących je charakterystycznych psowatych (wyobrażenia te przypominają szakala złocistego: Canis aureus, żyjącego m.in. na Bliskim Wschodzie, skądinąd słabo odróżnianego w antyku od psów i wilków - il. $10 b^{32}$ ).

Kolejna „mapa” w wyobrażeniach insygniów dowódców wojskowych Notitia dignitatum pars Orientis, tj. dux Mesopotamiae, w rękopisie Oxoniensis również od góry ma jasnoniebieski pas (Notitia dignitatum in partibus Orientis 36 - il. 11a-b). Zawiera ona $\mathrm{w}$ obu manuskryptach przedstawienia niebieskich wstęg mających wyobrażać rzeki: Fl[umen] Tigris i Fl[umen] Eufrates (z nazwą zapisaną $\mathrm{w}$ tle). Tygrys łagodnie meandruje $\mathrm{z}$ lewego górnego rogu do środkowej części „mapy”, zaś poniżej wyobrażono Eufrat. Obie rzeki umieszczono na tle koloru jasnozielonego o zróżnicowanym odcieniu i z kreskami w manuskrypcie Oxoniensis, a na tle jasnobrązowym w rękopisie $\mathrm{Mo}$ nacensis Latinus. Na górnym pasie tła widnieją trzy ustawione w jednej linii forty: Amida, Theodosiopolis i Amida (zob. nota 33). Z kolei pomiędzy wstęgami Tygrysu i Eufratu znajduje się osiem miejsc umocnionych: Constantina, Apadna i Constantina (w jednej linii), Cartha i Assara (w jednej linii), Thilbisme i Caini (w jednej linii) oraz Thannuri. Poniżej biegu Flumen Eufratus wyobrażono kolejne dwa castella: Celphae i Ripaltha.

prima miliaria Sebastena, Asuada. Ala Antana dromedariorum, Admatha. Ala Constantiana, Toloha. Ala secunda felix Ualentiana, apud Praesidium. Ala prima miliara, Hasta. Ala Idiota constituta. Cohors duodecima Ualeria, Afro. Cohors decima Carthaginensis, Cartha. Cohors prima agentenaria, Tarba. Cohors quarta Frygium, Praesidio. Cohors secunda Gratiana, Iehibo. Cohors prima equitata, Calamona. Cohors secunda Galatarum, Arieldela. Cohors prima Flauia, Moleatha. Cohors quarta Palaestinorum, Thamana. Cohors secunda Cretensis, iuxta Iordanem fluuium. Cohors prima salutaria, inter Aeliam et Hierichunta. Officium autem habet ita: Principem de scola agentum in rebus. Numerarios et adiutores eorum. Commentariensem. Adiutorem. A libellis siue subscribendarium. Exceptores et ceteros officiales". Por. Barrington Atlas, pl. 69-70.

${ }^{32}$ Por. Malinowski, Zwierzęta, s. 102-103 i 112. Wcześniej rozważałem jako równie prawdopodobne, że wyobrażenie mogło prezentować psy rasy Basenji, uznawanej za jedną z najstarszych ras psów i hodowanej także na tym obszarze, por. Wiewiorowski, Szczegóły, s. 161-162. Odstępuję od tego poglądu: dla rasy Basenji charakterystyczne jest bowiem umaszczenie brązowo-białe oraz podwinięty w górę ogon, co kontrastuje z wyobrażeniami ,psowatych” w insygniach dux Palestinae. Por. J.E. Johannes, Basenji Origin and Migration: Domestication and Genetic History, „The Official Bulletin of the Basenji Club of America” 37 (2003) 20-23. W przypadku tzw. „ras” psów domowych trudno wyciagać ostateczne konkluzje na podstawie źródeł antycznych, por. J. Aymard, Essai sur les chasses romaines des origines à la fin du siècle des Antonins (Cynegetica), Bibliothèque des Écoles Françaises d'Athènes et de Rome 171, Paris 1951, 235-274. Por. też przykłady omówione w: Dogs Through Time. An Archaeological Perspective Proceedings of the 1st ICAZ Symposium on the History of the Domestic Dog. Eighth Congress of the International Council for Archaeozoology (ICAZ 98), August 23-29, 1998, Victoria, B.C., Canada, ed. by S.J. Crockford, Oxford 2000, 141-190; oraz ogólnie na temat początków hodowli psów w starożytności: D. Brewer-T. Clark - A. Philips, Dogs in Antiquity: Anubis to Cerberus. The Origins of the Domestic Dog, Warminster 2001, passim. 
Nazwy fortów, co jak już wyżej podkreśliłem, odpowiadają przynajmniej częściowo nazwom miejsc stacjonowania oddziałów wojskowych podporządkowanych duksowi Mezopotamii według Notitia dignitatum. „Mapa” przypomina zaś współczesną mapę północnego Międzyrzecza zorientowaną na północ. Jak już miałem okazję pisać, usytuowanie fortów nie odpowiada jednak w najmniejszym stopniu ich rzeczywistej lokalizacji - il. $12^{33}$. Kolorystyka wyobrażeń znów jest jednak niezwykle realistyczna. Pojawić się może nawet pytanie czy jest możliwe, aby Péronet Lamy, iluminator rękopisu Oxoniensis, zdawał sobie sprawę z żyzności terenów nad górnym Eufratem oraz Tygrysem i dlatego użył zielonego koloru tła dla wywołania tego wrażenia? Obszar ten zaliczany jest wszak współcześnie do tzw. Żyznego Półksiężyca ${ }^{34}$.

Górna część wyobrażenie insygniów dux Armeniae według rękopisu Oxoniensis również zawiera pas niebieski. Przedstawienia fortów, usytuowanych na tle koloru jasnobrązowego o różnych odcieniach i z kreskami (Oxoniensis) lub jasnozielonego, podzielonego na dwie połowy przez jasnobrązową linię (Monacensis Latinus), w większości pozostają bez związku z ich rzeczywistą lokalizacją, a nazwy tylko w części korespondują z nazwami miejsc stacjonowania oddziałów wojskowych podporządkowanych duksowi Armenii według Notitia dignitatum (Notitia dignitatum in partibus Orientis 38: Sabbu, Domana, Apollinaris i Melitena oraz Auaxa, Siluanis i Trapezunta - il. 13a-b). Castellum Trapezunta umiejscowiono w prawym dolnym rogu „mapy”, blisko błękitnej plamy z wyrysowanymi czarnymi liniami, które to wyobrażenie przypomina falujący zbiornik wodny.

Dzięki temu szczegółowi i kolorystyce „mapa” ta dobrze oddaje realia geograficzne. Całość zaś zbliża się do współczesnej mapy tego obszaru

${ }^{33}$ Por. Wiewiorowski, Szczegóty, s. 162. Zob. Notitia dignitatum in partibus Orientis 36, 18-43, ed. Seeck, s. 78-79: „Sub dispositione uiri spectibilis ducis Mesopotamiae: Equites scutarii Illyriciani, Amidae. Equites promoti Illyriciani, Resain - Theodosiopoli. Equites ducatores Illyriciani [primi ducatores], Amidae. Equites felices Honoriani Illyriciani, Constantina. Equites promoti indigenae, Apadna. Equites promoti indigenae, Constantina. Equites sagittarii indigenae Arabanenses, Mefana - Cartha. Equites scutarii indigenae Pafenses, Assara. Equites sagittarii indigenae Thibithenses, Thilbisme. Equites sagittarii indigenae, Thannuri. Praefectus legionis primae Parthicae Nisibenae, Constantina. Praefectus legionis secundae Parthicae, Cefae. Et quae de minore laterculo emittuntur: Ala secunda noua Aegyptiorum, Cartha. Ala octaua Flauia Francorum, Ripaltha. Ala quintadecima Flauia Carduenorum, Caini. Cohors quinquagenaria Arabum, Bethallaha. Cohors quartadecima Ualeria Zabdenorum, Maiocariri. Officium autem habet ita: Principem de scola agentum in rebus. Numerarios et adiutores eorum. Commentariensem. Adiutorem. A libellis siue subscribendarium. Exceptores et ceteros officiales". Można zauważyć, że iluminator najwyraźniej nie zauważył, że według tekstu w forcie Amida stacjonowały dwie jednostki wojskowe (Equites scutarii Illyriciani i Equites ducatores Illyriciani); nie było natomiast dwóch fortów o nazwie Amida. Por. też Barrington Atlas, pl. 67, 89 i 91.

${ }^{34}$ Tzw. Żyzny Półksiężyc to pas ziem o większej żyzności (obecnie podlegający niestety degradacji pod wpływem aktywności człowieka), mający kształt wielkiego półksiężyca, ciagnnącego się od Egiptu poprzez Palestynę i Syrię po Mezopotamię, i w przeszłości będący kolebką wielkich cywilizacji rolniczych na Bliskim Wschodzie. Terminu tego po raz pierwszy użył egiptolog James H. Breasted, Ancient Times: A History of the Early World, Boston 1916. 
zorientowanej na południe: wszak Trapezunta/Trapezus, współczesny Trabzon, położony jest istotnie na wybrzeżu Morza Czarnego - il. $12^{35}$. Kolorystyka tła jest bliższa realiom środowiska naturalnego północno-wschodniego wybrzeża Anatolii w przypadku iluminacji autorstwa Péroneta Lamy.

Szczegóły geograficzne zawierają też insygnia dolnodunajskiego $d u x$ Scythiae (Notitia dignitatum in partibus Orientis 39 - il. 14a-b) ${ }^{36}$. Znów górny niebieski pas występuje w Oxoniensis. W obu analizowanych rękopisach wstęga z napisem Fl[umen] Danubius w tle ma ten sam kolor o nieco ciemniejszym odcieniu, przecinając „mapę” od lewego środkowego jej brzegu do dolnego prawego rogu i dzieląc ją na dwie części. Tło mapy ma kolor jasnozielony o zróżnicowanym odcieniu i z kreskami (Oxoniensis) lub jasnobrązowy (Monacensis Latinus). W górnej, większej części usytuowane są winiety czterech fortów: Flauiana, Capidaua, Cii i Beroe, podczas gdy część dolna zawiera winiety trzech fortów: Arubio, Aegissos i Thalamonio, których nazwy odpowiadają częściowo nazwom miejsc stacjonowania oddziałów wojskowych podporządkowanych duksowi Scytii według Notitia dignitatum.

„Mapa” odległa jest jednak od realiów geograficznych, tak w zakresie lokalizacji miejsc umocnionych, jak i przedstawienia Dunaju, którego nurt rozdzielał (i rozdziela) się na obszarze dawnej rzymskiej prowincji Scytia Mniejsza $\mathrm{w}$ istocie na kilka ramion - il. $15^{37}$. Kolorystyka tych insygniów jednak

${ }^{35}$ Por. Notitia dignitatum in partibus Orientis 38, 10-45, ed. Seeck, s. 83-85: „Sub dispositione uiri spectabilis ducis Armeniae: Equites sagittarii, Sabbu. Equites sagittarii, Domana. Praefectus legionis quintaedecimae Apollinaris, Satala. Praefectus legionis duodecimae fulminatae, Melitena. In Ponto: Praefectus legionis primae Ponticae, Trapezunta. Ala Rizena, Aladaleariza. Ala Theodosiana, apud Auaxam. Ala felix Theodosiana, Siluanis. Et quae de minore laterculo emittuntur: Ala prima Augusta Colonorum, Chiaca. Ala Auriana, Dascusa. Ala prima Ulpia Dacorum, Suissa. Ala secunda Gallorum, Aeliana. Ala castello Tablariensi constituta. Ala pima praetoria nuper constituta. Cohors tertia Ulpia miliaria Petraeorum, Metita. Cohors quarta Raetorum, Analiba. Cohors miliaria Bosporiana, Arauraca. Cohors miliaria Germanorum, Sisila. Ala prima Iouia felix, Chaszanenica. Ala prima felix Theodosiana, Pithiae. Cohors prima Theodosiana, Ualentia. Cohors Apuleia ciuium Romanorum, Ysiporto. Cohors prima Lepidiana, Caene - Parembole. Cohors prima Claudia equitata, Sebastopolis. Cohors secunda Ualentiana, Ziganne. Cohors, Mochora. Officium autem habet ita: Principem de scola agentum in rebus. Numerarios et adiutores eorum. Commentariensem. Adiutorem. A libellis siue subscribendarium. Exceptores et ceteros officiales”. Por. Barrington Atlas, pl. 64,87 i 89.

${ }^{36} \mathrm{Na}$ temat tego dowódcy oraz samej Scytii Mniejszej zob. Wiewiorowski, Stanowisko prawne, passim; tenże, Duces Scythiae Minoris, s. 11-17.

${ }^{37}$ Por. Wiewiorowski, Szczegóty, s. 164-165. Zob. Notitia dignitatum in partibus Orientis 39, 11-42, ed. Seeck, s. 86-88: „Sub dispositione uiri spectabilis ducis Scythiae: Cuneus equitum scutariorum, Sacidaua. Cuneus equitum Solensium, Capidaua. Cuneus equitum stablesianorum, Cii. Cuneus equitum stablesianorum, Bireo. Cuneus equitum catafractariorum, Arubio. Cuneus equitum armigerorum, Aegissos. Cuneus equitum Arcadum, Talamonio. Auxiliares: Milites nauclarii, Flauiana. Milites superuentores, Axiupoli. Milites Scythici, Carso. Milites secundi Constantini, Trosmis. Milites Scythici, Dirigothia. Milites primi Constantiani, Nouioduro. Milites quinti Constantiani, Salsouia. Milites primi Gratianenses, Gratiana. Item legiones riparienses: Praefectus legionis secundae Herculi[an]ae, Trosmis. Praefectus ripae legionis secundae Herculiae cohortis quintae peda- 
znów jest w miarę realistyczna. Jak i w poprzednich przypadkach bliższy realiom geograficznym był Péronet Lamy, bowiem obszary położone w dolnym biegu Dunaju obejmowały w czasach historycznych (tak jest zresztą i dziś) zarówno tereny uprawne jak i bagniska oraz lasy, co iluminator dobrze oddał za pomocą kolorystyki tła.

Natomiast Insygnia dux Arabiae, jak już zauważyłem wcześniej, są niezgodne z realiami geograficznymi i nie zawierają dodatkowych szczegółów topograficznych (Notitia dignitatum in partibus Orientis 37 - il. 16a-b i 10a) ${ }^{38}$. W centrum „mapy”, pomiędzy fortami Ziza, Mefa i Gadda, na tle jasnozielonym o różnych odcieniach według rękopisu Oxoniensis, zaś jednolicie jasnobrązowym według Monacensis Latinus, przedstawiono jednak trzy wijące się węże (w kolorze jasnoniebieskim, z ciemnoniebieskim grzbietem według $O x_{0}-$ niensis), z których dwa wyobrażono w pozie na wpół wyprostowanej. Z kolei u dołu widnieją dwa rozpościerające skrzydła stworzenia z zakrzywionymi dziobami i szponami w kolorze jasnoniebieskim, przypominające ptaki drapieżne (z żółtawymi dziobami według Oxoniensis). Wyobrażenia węży z Notitia dignitatum in partibus Orientis 37 mogą być ewentualnie przedstawieniem kobry egipskiej (Naja haje), lub kobry arabskiej (Naja haje arabica), największych

turae inferioris, Axiupoli. Praefectus ripae legionis secundae Herculiae cohortis quintae pedaturae inferioris, Iprosmis. Praefectus legionis primae Iouiae, Nouioduno. Praefectus ripae legionis primae Iouiae cohortis quintae pedaturae superioris, Nouioduno. Praefectus ripae legionis primae Iouiae cohortis quintae pedaturae inferioris, Accisso. Praefectus ripae legionis primae Iouiae cohortis [...] et secundae Herculiae musculorum Scythicorum et classis, Inplateypegiis. Officium autem habet ita: Principem de eodem officio, qui completa militia adorat protector. Numerarios et adiutores eorum. Commentariensem. Adiutorem. A libellis siue subscribendarium. Exceptores et ceteros officiales". Por. Barrington Atlas, pl. 23. Na temat lokalizacji miejsc umocnionych zob. C. Scorpan, Limes Scythiae. Topographical and stratiographical research on the Late Roman fortifications on the Lower Danube, British Archaeological Reports. International Series, 88, Oxford 1980, passim; M. Zahariade, Scythia Minor. A History of a Later Roman Province (284-681), Amsterdam 2006, 185-191.

${ }^{38}$ Por. Wiewiorowski, Szczegóty, s. 162-164. Animothia, Tricomia, Areopolis, Seluncis, Ziza, Mefa, Gadda, Bostra, Diafenses, Betthora - nazwy te odpowiadają w części nazwom miejsc stacjonowania oddziałów wojskowych podporządkowanych temu duksowi według Notitia dignitatum in partibus Orientis 37, 13-51, ed. Seeck, s. 81-82: „Sub dispositione uiri spectabilis ducis Arabiae: Equites scutarii Illyriciani, Motha. Equites promoti Illyriciani, Tricomia. Equites Dalmatae Illyriciani, Ziza. Equites Mauri Illyriciani, Areopoli. Equites promoti indigenae, Speluncis. Equites promoti indigenae, Mefa. Equites sagittarii indigenae, Gadda. Praefectus legionis tertiae Cyrenaicae, Bostra. Praefectus legionis quartae Martiae, Betthoro. Equites sagittarii indigenae, Dia - Fenis. Et quae de minore laterculo emittuntur: Ala nona miliaria, Auatha. Ala sexta Hispanorum, Gomoha. Ala secunda Constantiana, Libona. Ala secunda Miliarensis, Naarsafari. Ala prima Ualentiana, Thainatha. Ala secunda felix Ualentiniana, apud Adittha. Cohors prima miliaria Thracum, Adtitha. Cohors prima Thracum, Asabaia. Cohors octaua uoluntaria, Ualtha. Cohors tertia felix Arabum, in ripa Uade Afaris fluuii in castris Arnonensibus. Cohors tertia Alpinorum, apud Arnona. Officium autem [habet] uiri spectabilis ducis Arabiae et praesidis habet ita: Principem de scola agentum in rebus. Numerarios et adiutores eorum. Commentariensem. Adiutorem. A libellis siue subscribendarium. Exceptores et ceteros officiales". Por. Barrington Atlas, pl. 69-70. 
z przedstawicieli podrzędu Serpentes, żyjących na Bliskim Wschodzie ${ }^{39}$. Natomiast rozpowszechnionym gatunkiem ptaka drapieżnego na Półwyspie Arabskim jest raróg górski (Falco biarmicus), do dziś kojarzony z tym regionem ze względu na popularność sokolnictwa wśród Arabów, którego początki sięgają co najmniej czasów późnego antyku ${ }^{40}$. Węże te, jak i raróg górski nie mają jednak z pewnością niebieskiej barwy, jak chcieli je widzieć iluminatorzy w obu analizowanych manuskryptach, jakkolwiek ich zamieszczenie w pierwowzorze Notitia dignitatum w V w. mogło mieć na celu podkreślenie związek tych insygniów z terenami rzymskiego okręgu wojskowego noszącego miano Arabiail. 17a-b. W przypadku rękopisu Oxoniensis zwraca też uwagę kolorystyka tła, będącego wyobrażeniem gruntu, na którym iluminator, Péronet Lamy, umieścił rzeczone forty. Być może chciał on w ten sposób podkreślić przynależność tego terytorium do tzw. Żyznego Półksiężyca, tak jak to uczynił w przypadku wcześniej omówionego dukatu Mezopotamii.

$* * *$

Podsumowując, według communis opinio ilustracje insygniów wykonano zgodnie z późnoantycznymi kanonami iluminowania manuskryptów, którą kontynuowano następnie w Bizancjum ${ }^{41}$. Jak już wcześniej wspomniano, w świetle przeprowadzonej analizy insygniów widać, że iluminator/iluminatorzy późnoantycznego oryginału, a za nimi późniejsi kopiści Notitia dignitatum pars Orientis zapisywali w części poprawne nazwy miejsc umocnionych położonych na danym terenie i w niektórych insygniach zamieszczali też charakterystyczne dla danego obszaru szczegóły topograficzne. Moim zdaniem podobną rolę pełniły też umieszczone tam zwierzęta, kojarzone $\mathrm{z}$ danym regionem ${ }^{42}$.

${ }^{39}$ Węże cieszyły się w średniowieczu szczególnie złą sławą, m.in. z powodu biblijnej konotacji tych zwierząt z szatanem (np. Rdz 3), w odróżnieniu od antyku, kiedy kojarzono węże z lecznictwem, a niekiedy trzymano nawet jako zwierzęta domowe. Por. F.D. Lazenby, Greek and Roman Household Pets, „Classical Journal” 44 (1947) 245-252 i 299-307; F.P. Retief - L. Cilliers, Snake and staff symbolism and healing, „Acta Theologica. Supplementum” 7 (2005) 189-199. Co ciekawe ludzie, tak jak i inni przedstawiciele Naczelnych (Primates) mają wrodzoną zdolność szybszego odróżniania przedstawicieli serpentes od innych zwierząt. Jest to tłumaczone ewolucyjnie wykształconą umiejętnością, ułatwiającą unikanie zagrożeń jakie stwarzały węże - tzw. Snake Detection Theory. Por. L.A. Isbell, The Fruit, the Tree, and the Serpent. Why We See So Well, Cambridge Mass. - London 2009, passim; J.W. Van Strien - L.A. Isbell, Snake scales, partial exposure, and the Snake Detection Theory: A human event-related potentials, „Scientific Reports” 7 (2017) - tekst jest dostępny pod adresem: https://www.nature.com/articles/srep46331 [dostęp: 10 I 2018].

${ }^{40}$ Por. P. Badyna, Bładzqc za sokołami, „Kultura - Historia - Globalizacja” 12 (2012) 1-19; Malinowski, Zwierzęta, s. 173. Średniowieczne wyobrażenia ptaków w manuskryptach nawiązywały przy tym z reguły do antycznych wzorów, por. J. Anker, Bird Books And Bird Art. An Outline Of The Literary History And Iconography Of Descriptive Ornithology, Copenhagen 1938, 3-6.

${ }^{41}$ Por. A. Grabar, The Art of the Byzantine Empire: Byzantine Art in Middle Ages, transl. by B. Forster, New York 1967, 167-183 i 194-195.

${ }^{42}$ Por. Wiewiorowski, Szczegóły, passim. Jak słusznie zaznaczyła Pamela C. Berger (The In- 
Te elementy ikonograficzne pełniły funkcję wzmocnienia kojarzenia treści przedstawionych w insygniach i w tekście Notitia dignitatum z określonymi, odległymi geograficznie regionami imperium u odbiorców tego dokumentu, którymi byli głównie przedstawiciele elit późnorzymskich ${ }^{43}$.

W świetle przeprowadzonej tutaj analizy można podnieść jeszcze jedną kwestię. Oto twórcy iluminacji obu analizowanych rękopisów w kontekście szczegółów geograficznych, odmiennie niż można ewentualnie domniemywać w innych elementach graficznych insygniów Notitia dignitatum ${ }^{44}$, nie uwzględnili charakterystycznej dla antyku i średniowiecza symboliki kolorów, w tym symboliki wypracowanej w malarstwie ikonowym ${ }^{45}$. Kolorystyka wyobrażeń rzek, akwenów wodnych, zwierząt a nawet gruntów w przypadku obu iluminatorów nie była jednak przypadkowa, ani nie pełniła wyłącznie funkcji zdobniczej. Adekwatne kolory w stosunku do szczegółów geograficznych stosował zwłaszcza iluminator Oxoniensis, Péronet Lamy ${ }^{46}$. Iluminacje wykonane przez niego wskazują, że różnicował on nawet kolorystykę tła w zależności od tego, kiedy chciał przedstawić grunt w „mapach”, odpowiadający różnym rejonom geograficznych imperium. Dostrzec to można również w iluminacjach poddanych analizie w niniejszym tekście ${ }^{47}$. W zakresie stylu wyobrażeń kierował się

signia, s. 119-120), autorka najbardziej wnikliwej dotąd analizy insygniów w Notitia dignitatum: „Though the basis of the Notitia maps was not a cartographic source, it is clear that the late antique illustrator in the East was both familiar with the geography of certain areas and also was acquainted with documents like the archetypes of Tabula Pentigueriana and the Agrimensores. [...] Thus the person or persons who drew up these maps had some knowledge of geography; this knowledge would account for the inclusions of the occasionally accurate topographical allusion". Warto w tym miejscu pamiętać, iż według części autorów państwowa sztuka rzymska służyła w mniejszym stopniu rzeczywistości historycznej, a bardziej do egzemplifikacji określonej idei. Por. T. Hölscher, Sztuka rzymska: język obrazowy jako system semantyczny, thum. L. Olszewski, Poznań 2011, 210-211. Posługiwanie się pojęciem „sztuka” w kontekście starożytności jest przy tym przedmiotem kontrowersji. Por. L. Olszewski, Od tlumacza. „Co rzymskiego jest w sztuce rzymskiej”, czyli o koncepcji języka obrazowego jako systemie semantycznym Tonio Hölschera, w: Hölscher, Sztuka rzymska, s. 11.

${ }^{43}$ Być może Notitia dignitatum była sporządzona pierwotnie dla edukacji samego Teodozjusza II (401-450), a później wykorzystywana w kształceniu Walentyniana III (419-455). Por. Traina, Mapping the world, s. 162-163.

${ }^{44}$ M.in. na przykładzie wikariuszy diecezji, por. Wiewiorowski, The Judiciary, s. 236-256.

${ }^{45}$ Por. L. Uspienski, Teologia ikony, tłum. M. Żurowska, Poznań 1993, 120-156; J. Gage, Color and Culture: Practice and Meaning from Antiquity to Abstraction, Berkeley - Los Angeles 1999, 29-92; L. James, Color and Meaning in Byzantium, JECS 11 (2003) nr 2, 223-233; M. Bradley, Color and Meaning in Ancient Rome, Cambridge 2009, 189-211. Por. też K. Jurek, Znaczenie symboliczne i funkcje koloru w kulturze, „Kultura - Media - Teologia” 6 (2011) 68-80.

${ }^{46}$ Kolorystyka tła - „gruntu” w przypadku dukatu Mezopotamii - mogła być echem wiedzy Péroneta Lamy o żyzności obszaru Międzyrzecza w okresie przed zniszczenia sieci irygacyjnej przez Tamerlana (1336-1405) w trakcie najazdu w latach 1393-1394. Za sugestię tę dziękuję dr Piotrowi Ł. Grotowskiemu (Katedra Historii Sztuki Starożytnej i Średniowiecznej, Uniwersytet Jana Pawła II w Krakowie).

${ }^{47} \mathrm{Z}$ pewnością nie można mówić w tym przypadku o tzw. „błędzie poznawczym” (cognitive bias), który oznacza ogólne określenie wzorca nieracjonalnego spostrzegania rzeczywistości, mają- 
on przypuszczalnie swoimi osobistymi gustami. W przypadku analizowanych ilustracji widać to przez pryzmat wyobrażeń miejsc umocnionych, które Péronet Lamy stylizował na budowle gotyckie ${ }^{48}$. Niektórzy badacze przypuszczaja jednak, że w zakresie kolorystyki iluminator ten trzymał się wzoru zaczerpniętego z Codex Spirensis (a ten zapewne pierwowzoru z V w.) ${ }^{49}$. Natomiast anonimowy iluminator Monacensis Latinus skrupulatniej podążał za stylistyką iluminacji Codex Spirensis ${ }^{50}$. Także u niego widać inklinację do stosowania w przypadku szczegółów geograficznych oraz wyobrażeń zwierząt kolorów odpowiadających pierwowzorom (zwłaszcza w przypadku rzek, zbiorników wodnych i części zwierząt).

Pozwala to wysnuć roboczy wniosek, że zastosowana w obu rękopisach kolorystyka szczegółów geograficznych, a także kolorystyka części przedstawionych zwierząt pełniła funkcję wzmocnienia kojarzenia przedstawionych „map” z określonymi regionami geograficznymi imperium.

Wyobrażenia przedstawione w iluminacjach zawierających szczegóły geograficzne nie były całkiem zgodne z rzeczywistością, jednak pozwalały one odbiorcom treści przekazywanych przez ilustracje i tekst Notitia dignitatum porządkować obraz świata. Jako ludzie przychodzimy na świat wyposażeni we wrodzoną zdolność odróżniania kolorów (czerwonego, zielonego, niebieskiego, fioletowego i żółtego), przy czym to kultura i język decydują o ich późniejszym wykorzystaniu ${ }^{51}$. Ludzkie umysły działają też m.in. według schematu rozpoznawania wzorców i reguł myślenia stereotypowego, które również są

cego wpływ na ludzkie postawy, emocje, rozumowanie lub zachowania (działania). Pojęcie to zdefiniowali, pierwotnie na gruncie psychologii Daniel Kahneman i Amos Tversky - pierwszy artykuł temu poświęcony opublikowali w roku 1972: D. Kahneman - A. Tversky, Subjective probability: A judgment of representativeness, „Cognitive Psychology” 3 (1972) nr 3, 430-454. Por. M.G. Haselton - D. Nettle - P.W. Andrews, The Evolution of Cognitive Bias, w: The Handbook of Evolutionary Psychology, ed. by D.M. Buss, Hoboken 2005, 724-746. Na temat użyteczności sięgania do tego pojęcia na gruncie badań historyczno-prawnych zob. W. Dajczak, Błędy poznawcze a tęsknota za użytecznościa nauki prawa rzymskiego, „Forum Prawnicze” 17 (2013) nr 3, 9-20.

${ }^{48}$ Źródłem inspiracji było dla niego późnośredniowieczne malarstwo niderlandzkie, por. nota 6.

${ }^{49}$ Por. Berger, The Insignia, s. 15-17 i 22-23.

${ }^{50}$ Modernizowanie wyobrażeń przez Péroneta Lamy w Oxoniensis Canonicianus Misc. 378 była jedną z przyczyn, dla których sporządzono Monacenis Latinus 10291: miał on oddać bardziej wiarygodnie styl iluminacji Codex Spirensis. Por. literaturę cytowaną w notach 1-7.

${ }^{51}$ Por. D. Robertson, Evolution, culture, and human mind, w: Evolution, Culture, and the Human Mind, ed. by M. Schaller - A. Norenzayan - S.J. Heine - T. Yamagishi - T. Kameda, New York - London 2009, 167-184; N.L. Komarova - I.K.A. Jameson - I.L. Narens, Evolutionary Models of Color Categorization Based on Discrimination, „Journal of Mathematical Psychology” 51 (2007) nr 6, 359-382; A.E. Skelton - G. Catchpole - J.T. Abbott - J.M. Bosten - A. Franklin, Biological origins of color categorization, „Proceedings of the National Academy of Sciences” 114 (2017) $\mathrm{nr}$ 21, 5545-5550. Por. też przegląd poglądów: A.J. Elliot, Color and psychological functioning: a review of theoretical and empirical work, „Frontiers in Psychology” 6/368 (2015) - publikacja ta znajduje się pod adresem: https://www.frontiersin.org/articles/10.3389/fpsyg.2015.00368/full [dostęp: 10 I 2018]. 
wrodzone $^{52}$. Uwarunkowania te intuicyjnie uwzględnili iluminatorzy obu analizowanych manuskryptów, ułatwiając za pomocą wykorzystanych motywów oraz ich kolorystyki kojarzenie tekstu wschodniej części Notitia dignitatum z określonym regionem geograficznym ${ }^{53}$. Charakterystyczne przy tym, że zabieg ten dotyczył obszarów traktowanych jako peryferyjne z punktu widzenia centralnej administracji cesarskiej w Konstantynopolu ${ }^{54}$.

I na koniec nieśmiała uwaga: powyższy przykład dowodzi, co staram się podkreślać od lat, że nauki historyczne powinny sięgać do osiągnięć współczesnych nurtów ewolucyjnych w naukach przyrodniczych ${ }^{55}$. Pozwalają one m.in. pełniej interpretować wytwory materialnej kultury człowieka, a do takich należą też wyobrażenia insygniów w Notitia dignitatum. Kompleksowe zrozumienie przesłanek zjawisk i procesów historycznych nie jest również bez nich możliwe, co nadaje nowy i głęboki sens powiedzeniu historia magistra

\footnotetext{
${ }^{52} \mathrm{Na}$ temat ewolucyjnych korzeni myślenia stereotypowego por. Haselton - Nettle - Andrews, The Evolution of Cognitive Bias, passim; Evolution and the Social Mind, passim. Wyrażone stanowisko zgodne jest z paradygmatem psychologii ewolucyjnej. Na jej temat por. D.M. Buss, Psychologia ewolucyjna, thum. M. Orski, Gdańsk 2001, passim; The Handbook of Evolutionary Psychology, passim; The Oxford Handbook of Evolutionary Psychology, ed. by R.I.M. Dunbar - L. Barret, Oxford 2007, passim; The Handbook of Evolutionary Psychology, vol. 1-2, ed. by D.M. Buss, Hoboken 2015, passim. Por. też B. Pawłowski - D. Danel, Psychologia ewolucyjna - nauka o adaptacjach i ewolucyjnej inercji ludzkiego umystu, „Kosmos” 58 (2009) 573-583.

${ }^{53} \mathrm{~W}$ podobnym duchu wobec późnoantycznych spisów miejsc i terytoriów wypowiedział się ostatnio: S.F. Johnson, Literary Territories: Cartographical Thinking in Late Antiquity, Oxford 2016, 38 i 148.

${ }^{54}$ Por. Millar, Greek Roman Empire, s. 8-10. Autor zasadnie wskazuje, iż miejsca wydania cesarskich konstytucji z czasów Teodozjusza II, czyli Konstantynopol i okoliczne prowincje „are a real reflection of the working of a «Roman» regime in a world of Greek cities".

${ }^{55}$ Por. Wiewiorowski, The Judiciary, s. 291-292; tenże, Homo religiosus sum, „Czas Kultury” 186 (2015) nr 3, 194-204; idem, Deformed child in the Twelve Tables, w: Mater Familias. Scritti Romanistici per Maria Zabłocka, a cura di Z. Benincasa - J. Urbanik, con la collaborazione di P. Niczyporuk - M. Nowak, Varsovia 2016, 1157-1176; tenże, Dopuszczalność zabójstwa kalekiego noworodka w pogańskim Rzymie, w: Zabójstwo dziecka w literaturze i kulturze europejskiej, red. K. Ilski - M. Chmielarz - Z. Kopeć - E. Kraskowska, Badania Interdyscyplinarne 36, Poznań 2016, 23-40; tenże, Prohibition of retroactive law - a historical key to intertemporary law, w: The Intertemporal Problems in Law, ed. by J. Mikołajewicz - W. Szafrański - A. Godek, Poznań 2017, 25-54. O możliwościach i potrzebie wykorzystywania ustaleń współczesnych nurtów ewolucjonizmu w ramach „humanities” por. The Sociobiological Imagination, ed. by M. Maxwell, Albany 1991, passim; Missing the Revolution: Darwinism for Social Scientists, ed. by J.H. Barkow, Oxford 2006, passim; W. Burkert, Stwarzanie świetości. Ślady biologii we wczesnych wierzeniach religijnych, thum. L. Trzcionkowski, Kraków 2006, 25-42; W. Załuski, Ewolucyjna filozofia prawa, Warszawa 2009, passim; Applied Evolutionary Psychology, ed. by S.C. Roberts, Oxford 2011, passim; K.T. Ulrich, Design. Creation of Artifacts in Society, University of Pennsylvania [2012] - tekst ten jest dostępny pod adresem: http://opim.wharton.upenn.edu/ ulrich/designbook.html (spec. s. 97-109) [dostęp: 10 I 2018]; F. Fukuyama, Historia ładu politycznego. Od czasów przedludzkich do rewolucji francuskiej, thum. N. Radomski, Poznań 2012, 42-100.
} 
vitae est $t^{56}$. Ewolucyjnie ukształtowana natura ludzka oraz schematy funkcjonowania ludzkiego umysłu nie uległy bowiem większym zmianom pomimo odrębności realiów współczesnego świata i starożytności ${ }^{57}$.

\author{
THE COLOURS OF TOPOGRAPHICAL ALLUSIONS \\ IN NOTITIA DIGNITATUM PARS ORIENTIS \\ ACCORDING TO OXONIENSIS CANONICIANUS MISC. 378 \\ AND MONACENSIS LATINUS 10291
}

\title{
(Summary)
}

The text analyses the reality of the colours used in the topographical allusions of the insignia of late Roman officials, known from the Notitia dignitatum in partibus Orientis from the turn of the $5^{\text {th }}$ century, preserved in Oxoniensis Canonicianus Misc. 378 and Monacensis Latinus 10291 - Not. Dig. Or. 28, 29, 31, 34, $36,38,39,37$. The author links the accuracy of colours used by the illustrators of the insignia with the intention of the Notitia dignitatum to give the emperor and other members of late Roman elite a relatively coherent picture of the geographically remote regions of the Eastern Roman Empire. He subsequently relates it to the functioning of human brain as a pattern recognizer shared universally by human beings, despite that colour perception among Humans is strongly affected by culture and calling for the inclusion of data collected by evolutionary psychology and other evolutionary research in historical studies.

Key words: Notitia dignitatum in partibus Orientis, Oxoniensis Canonicianus Misc. 378, Monacensis Latinus 10291, topographical allusions, colour perception among Humans, Evolutionary Psychology.

Słowa kluczowe: Notitia dignitatum in partibus Orientis, Oxoniensis Canonicianus Misc. 378; Monacensis Latinus 10291, szczegóły geograficzne, percepcja barw u ludzi, psychologia ewolucyjna.

${ }^{56}$ Cicero, De oratore II 9, 36, ed. E.W. Sutton: Cicero, [Works], vol. 3: De oratore (Books I-II), with an introd. by H. Rackham, LCL 348, Cambridge Mass. - London 1996, 224: „Historia vero testis temporum, lux veritatis, vita memoriae, magistra vitae, nuntia vetustatis, qua voce alia nisi oratoris immortalitati commendatur?”, thum. B. Awianowicz: Cyceron, O mówcy, Kęty 2010, 258-259: „Czyj wreszcie głos, jeśłi nie mówcy, powierzy nieśmiertelności historię, świadka czasów, światło prawdy, życie pamięci, nauczycielkę życia, posłankę dawnych dziejów”.

${ }^{57}$ Por. J. Alcock, The Triumph of Sociobiology, Oxford 2001, 149-187. Na temat relacji między biologiczną naturą człowieka a kultura, zob. S. Pinker, Tabula rasa. Spory o naturę ludzka, thum. A. Nowak, Gdańsk 2005, passim. Autor poddaje tam gruntownej krytyce tezy współczesnych przeciwników istnienia uniwersalnej natury ludzkiej oraz wskazuje na niebezpieczeństwa płynące z ich poglądów. 


\section{BIBLIOGRAFIA}

\section{Źródła}

Cicero, De oratore, ed. and trans. by E.W. Sutton: Cicero, [Works], vol. 3: De oratore (Books I-II), with an introd. by H. Rackham, LCL 348, Cambridge Mass. - London 1996, tłum. B. Awianowicz: Cyceron, O mówcy, Kęty 2010.

La ,Notitia dignitatum": nueva edición crítica y comentario histórico, [ed.] C. Neira Faleiro, Nueva Roma 25, Madrid 2005.

Notitia dignitatum omnium, tam ciuilium quam militarium, in partibus Orientis, ed. O. Seeck: Notitia dignitatum: accedunt notitia urbis Constantinopolitanae et laterculi prouinciarium, Berolini 1876, 1-102.

Notitia dignitatum omnium, tam ciuilium quam militarium, in partibus Occidentis, ed. O. Seeck: Notitia dignitatum: accedunt notitia urbis Constantinopolitanae et laterculi prouinciarium, Berolini 1876, 103-225.

\section{Opracowania}

ALcock J., The Triumph of Sociobiology, Oxford 2001.

AleXander J.J.G., The illustrated manuscripts of the Notitia Dignitatum, w: tenże, Studies in Italian manuscript illumination, London 2002, 65-98.

AnKer J., Bird Books And Bird Art. An Outline Of The Literary History And Iconography Of Descriptive Ornithology, Copenhagen 1938.

Applied Evolutionary Psychology, ed. by S.C. Roberts, Oxford 2011.

Aymard J., Essai sur les chasses romaines des origines à la fin du siècle des Antonins (Cynegetica), Bibliothèque des Écoles Françaises d'Athènes et de Rome 171, Paris 1951.

BADYNA P., Bładzac za sokołami, „Kultura - Historia - Globalizacja” 12 (2012) 1-19.

Baldwin B., Better Late and Early: Reflections on the Date of Calpurnius Siculus, „Illinois Classical Studies" 20 (1995) 157-167.

Barrington Atlas of the Greek and Roman World, ed. by R. Talbert, Princeton - Oxford 2000. Berger P.C., The Insignia of the „Notitia Dignitatum”. A Contribution to the Study of the Late Antique Illustrated Manuscripts, New York - London 1981.

Berschin W., Grecko-łacińskie średniowiecze. Od Hieronima do Mikotaja z Kuzy, thum. K. Liman, Gniezno 2003.

BonfiLs G. DE, Il comes et quaestor nell'età della dinastia costantiniana, Napoli 1981.

Bradley M., Color and Meaning in Ancient Rome, Cambridge 2009.

BREAsted J.H., Ancient Times: A History of the Early World, Boston 1916.

Brennan P., The „Notitia Dignitatum”, w: Les littératures techniques dans l'antiquité romaine. Statut, public et destination, tradition. Sept exposés suivis de discussions, Vandøuvres-Genève, 21-26 aoû 1995, éd. par C. Nicolet, Entretiens sur l'Antiquité Classique 42, Genève 1996, 147-178.

Brennan P., The user's guide to the Notitia Dignitatum: the case of the Dux Armeniae (ND Or. 38), „Antichthon” 32 (1998) 34-49.

Brewer D. - Clark T. - Philips A., Dogs in Antiquity: Anubis to Cerberus. The Origins of the Domestic Dog, Warminster 2001.

Burgess JR. W.D., Isauria and the Notitia Dignitatum, „The Ancient World” 26 (1995) nr $1,79-88$.

BURKERT W., Stwarzanie świętości. Ślady biologii we wczesnych wierzeniach religijnych, thum. L. Trzcionkowski, Kraków 2006.

Buss D.M., Psychologia ewolucyjna, tłum. M. Orski, Gdańsk 2001. 
Calvignac S. [ET AL.], Ancient DNA evidence for the loss of a highly divergent brown bear clade during historical times, „Molecular Ecology” 17 (2008) 1962-1970.

Carlá F. - Castello M.G., Questioni tardoantichi. Storia e mito della „, svolta constantiniana”, Roma 2010.

CARrié J.-M., Séparation ou cumul? Pouvoir civil et autorité militaire dans les provinces d'Égypte de Gallien à la conquête arabe, „Antiquité Tardive” 6 (1998) 105-121.

Chastagnol A., La préfecture urbaine a Rome sous le Bas-Empire, Paris 1960.

DAJCZAK W., Błędy poznawcze a tęsknota za użytecznościq nauki prawa rzymskiego, „Forum Prawnicze" 17 (2013) nr 3, 9-20.

DARIo B.M. DI, La Notitia Dignitatum. Immagini e symboli del Tardo Impero Romano, Padova 2006.

Delbrück R., Die Consulardiptychen und verwandte Denkmäler, Bd. 1: Text, Studien zur Spätantiken Kunstgeschichte 2/1, Berlin - Leipzig 1929.

Dilke O.A.W., Itineraries and Geographical Maps in the Early and Late Roman Empires, w: The History of Cartography, vol. 1: Cartography in prehistoric, ancient, and medieval Europe and the Mediterranean, ed. by J.B. Harley - D. Woodward, Chicago 1987, 244-257.

Dogs Through Time. An Archaeological Perspective Proceedings of the 1st ICAZ Symposium on the History of the Domestic Dog. Eighth Congress of the International Council for Archaeozoology (ICAZ 98), August 23-29, 1998, Victoria, B.C., Canada, ed. by S.J. Crockford, Oxford 2000.

Dölger F. - Karayannopulos J., Byzantinische Urkundenlehre, München 1968.

Edmunds SH., The Missals of Felix V and Early Savoyard Illumination, „The Art Bulletin” 46 (1964) nr 2, 127-141.

Elliot A.J., Color and psychological functioning: a review of theoretical and empirical work, „Frontiers in Psychology” 6/368 (2015) - tekst jest dostepny pod adresem: https:// www.frontiersin.org/articles/10.3389/fpsyg.2015.00368/full [dostęp: 10 I 2018].

Elton H., The Nature of the Sixth-century Isaurians, w: Ethnicity and Culture in Late Antiquity, ed. by S. Mitchell - G. Greatrex, London 2000, 293-307.

ENGEMANN J., Herrscherbild, RACh XIV 966-1047.

Evolution and the Social Mind. Evolutionary Psychology and the Social Cognition, ed. by W. von Hippel - M. Haselton - J.P. Forgas, New York 2007.

Feld K., Barbarische Bürger. Die Isaurier und das Römische Reich, Berlin - New York 2005.

Fukuyama F., Historia ładu politycznego. Od czasów przedludzkich do rewolucji francuskiej, tłum. N. Radomski, Poznań 2012.

Gage J., Color and Culture: Practice and Meaning from Antiquity to Abstraction, Berkeley - Los Angeles 1999.

Gencheva-Mikami I., Personification in impersonal context: late Roman bureaucracy and the illustrated Notitia dignitatum, w: Personification in the Greek world: from antiquity to Byzantium, ed. by E. Stafford - J. Herrin, Ashgate 2005, 285-291.

Grabar A., The Art of the Byzantine Empire: Byzantine Art in Middle Ages, transl. by B. Forster, New York 1967.

Grigg R., Illustrations and Text in the lost Codex Spirensis, „Latomus” 46 (1987) nr 1, 204-210.

GrigG R., Inconsistency and Lassitude: The Shield Emblems of the Notitia Dignitatum, JRS 73 (1983) 132-142.

GRIGG R., Portrait-Bearing Codicils in the Illustration of the „Notitia Dignitatum”?, JRS 59 (1979) 107-124. 
Haselton M.G. - Nettle D. - Andrews P.W., The Evolution of Cognitive Bias, w: The Handbook of Evolutionary Psychology, ed. by D.M. Buss, Hoboken 2005, 724-746.

HöLsCher T., Sztuka rzymska: język obrazowy jako system semantyczny, thum. L. Olszewski, Poznań 2011.

Isbell L.A., The Fruit, the Tree, and the Serpent. Why We See So Well, Cambridge Mass. - London 2009.

JAMES L., Color and Meaning in Byzantium, JECS 11 (2003) nr 2, 223-233.

Jennison G., Animals for Show and Pleasure in Ancient Rome, Manchester 1937.

Johannes J.E., Basenji Origin and Migration: Domestication and Genetic History, „The Official Bulletin of the Basenji Club of America" 37 (2003) 20-23.

Johnson S.F., Literary Territories: Cartographical Thinking in Late Antiquity, Oxford 2016. Jones A.H.M., The Cities of the Eastern Roman Provinces, Oxford 19712.

JUREK K., Znaczenie symboliczne i funkcje koloru w kulturze, „Kultura - Media - Teologia" 6 (2011) 68-80.

KÁDÁr Z., Some zoogeographical aspects of the NW African vertebrate fauna in historical times: archeological and cultural historical methods in the research, „Vertebrata Hungarica" 18 (1978) 79-83.

Kahneman D. - Tversky A., Subjective probability: A judgment of representativeness, „Cognitive Psychology” 3 (1972) nr 3, 430-454.

KarLOWA O., Römische Rechtsgeschichte, vol. 1, Leipzig 1885.

Kelly CH., Notitia dignitatum, w: The Classical Tradition, ed. by A. Grafton - G.W. Most - S. Settis, Cambridge Mass. - London 2010, 640-641.

Komarova N.L. - JAmeson I.K.A. - NArens I.L., Evolutionary Models of Color Categorization Based on Discrimination, ,Journal of Mathematical Psychology” 51 (2007) nr 6, 359-382.

Kos P., Barriers in the Julian Alps and Notitia Dignitatum, „Acta Archaeologica” 65 (2014) 409-422.

Kosiński R., Izauria w orbicie wpływów rzymskich do połowy V wieku, „Białostockie Teki Historyczne" 8 (2010) 11-26.

Kulikowski M., The „Notitia Dognitatum” as a Historical Source, „Historia” 49 (2000) 358-377.

Lazenby F.D., Greek and Roman Household Pets, „Classical Journal” 44 (1947) 245-252 i 299-307.

Lenski N., Assimilation and Revolt in the Territory of Isauria, From the 1st Century BC to the 6th Century AD, ,Journal of the Economic and Social History of the Orient” 42 (1999) 413-465.

Loerke W.C., The Miniatures of the Trial in the Rossano Gospels, „The Art Bulletin” 43 (1961) nr 2, 171-195.

MacKInnon M., Supplying Exotic Animals for the Roman Amphitheatre Games: New Reconstructions Combining Archaeological, Ancient Textual, Historical and Ethnographic Data, „Mouseion” 6 (2006) 137-161.

Maier I.C., The Barberinus and Munich Codices of the „Notitia Dignitatum omnium”, „Latomus” 28 (1969) nr 4, 960-1035.

Malinowski G., Zwierzęta świata antycznego. Studia nad „Geografia” Strabona, Wroclaw 2003.

Malinowski G., Źródła do Pliniuszowego opisu zwierzęcia zwanego eale (Naturalis Historia VIII 73), „Acta Universitatis Wratislaviensis. Classica Wratislaviensia” 20 (1996) 101-107.

Marotta V., Mandata Principum, Torino 1991. 
Millar F., Greek Roman Empire. Power and Belief under Theodosius II (408-450), Berkeley - Los Angeles - London 2006.

Missing the Revolution: Darwinism for Social Scientists, ed. by J.H. Barkow, Oxford 2006.

O'Hara R., An Assessment of the Notitia Dignitatum as a Historical Source for the Late Roman Bureaucracy, Maynooth 2013 - tekst jest dostępny pod adresem: http:// eprints.maynoothuniversity.ie/4593/ [dostęp: 10 I 2018].

Olszewski L., ,, Od ttumacza. ,, Co rzymskiego jest w sztuce rzymskiej”, czyli o koncepcji języka obrazowego jako systemie semantycznym Tonio Hölschera, w: T. Hölscher, Sztuka rzymska: język obrazowy jako system semantyczny, tłum. L. Olszewski, Poznań 2011, 11-30.

Palme B., The imperial presence: Government and army, w: Egypt in the Byzantine World, 300-700, ed. by R.S. Bagnal, Cambridge 2007, 240-270.

PawŁowski B. - DAnel D., Psychologia ewolucyjna - nauka o adaptacjach $i$ ewolucyjnej inercji ludzkiego umystu, „Kosmos” 58 (2009) 573-583.

PInker S., Tabula rasa. Spory o naturę ludzka, tłum. A. Nowak, Gdańsk 2005.

PolascheK E., Notitia dignitatum, RE XVII/1, 1077-1116.

Price R.M., The limes of Lower Egypt, w: Aspects of the Notitia Dignitatum, ed. by R. Goodburn - R. Bartholemew, British Archaeological Reports. Supplementary Series 15, Oxford 1976, 143-154.

Retief F.P. - Cilliers L., Snake and staff symbolism and healing, „Acta Theologica Supplementum" 7 (2005) 189-199.

Robertson D., Evolution, culture, and human mind, w: Evolution, Culture, and the Human Mind, ed. by M. Schaller - A. Norenzayan - S.J. Heine - T. Yamagishi - T. Kameda, New York - London 2009, 167-184.

Salway B., Putting the world in order: mapping in Roman texts, w: Ancient Perspectives: Maps and Their Place in Mesopotamia, Egypt, Greece, and Rome, ed. by R.J.A. Talbert, Chicago 2012, 193-234.

Scharf R., Comites und comitiva primi ordinis, Mainz 1994.

Scharf R., Der Dux Mogontiacensis und die Notitia Dignitatum. Eine Studie zur spätantiken Grenzverteidigung, Berlin - New York 2005.

Scorpan C., Limes Scythiae. Topographical and stratiographical research on the Late Roman fortifications on the Lower Danube, British Archaeological Reports. International Series 88, Oxford 1980.

SeEck O., Codicilli 5, RE IV 179-183.

SeIBT W., Notitia dignitatum, w: Reallexikon zur byzantinischen Kunst, vol. 7, hrsg. von K. Wessel - M. Restle, Stuttgart 2004, 1030-1046.

SHAw B.D., Bandit Highlands and Lowland Peace: The Mountains of Isauria-Cilicia, „,ournal of the economic and social history of the Orient" 33 (1990) 199-233.

Sivan H., Palestine in Late Antiquity, Oxford 2008.

Skelton A.E. - Catchpole G. - Aвbott J.T. - Bosten J.M. - Franklin A., Biological origins of color categorization, „Proceedings of the National Academy of Sciences” 114 (2017) nr 21, 5545-5550.

Strien J.W. Van, Isbell L.A., Snake scales, partial exposure, and the Snake Detection Theory: A human event-related potentials, „Scientific Reports” 7 (2017) - tekst jest dostępny pod adresm: https://www.nature.com/articles/srep46331 [dostęp: 10 I 2018].

Szopa A., Notitia Dignitatum - „,najbardziej rzymski z dokumentów”?, „Annales Universitatis Paedagogicae Cracoviensis. Studia Historica” 8 (2009) 183-191.

TAlBeRT R.J.A., Rome's world: the Peutinger map reconsidered, New York 2010.

The Handbook of Evolutionary Psychology, ed. by D.M. Buss, Hoboken 2005. 
The Handbook of Evolutionary Psychology, vol. 1-2, ed. by D.M. Buss, Hoboken 2015.

The Oxford Handbook of Evolutionary Psychology, ed. by R.I.M. Dunbar - L. Barret, Oxford 2007.

The Sociobiological Imagination, ed. by M. Maxwell, Albany 1991.

Toynbee J.M.C., Animals in Roman Life and Art, London 1973.

Traina G., Mapping the world under Theodosius II, w: Theodosius II: Rethinking the Roman Empire in Late Antiquity, ed. by Ch. Kelly, Cambridge 2013, 155-171.

Ulrich K.T., Design. Creation of Artifacts in Society, University of Pennsylvania [2012] - tekst jest dostępny pod adresem: http://opim.wharton.upenn.edu/ ulrich/designbook.html [dostęp: 10 I 2018].

Uspienski L., Teologia ikony, tłum. M. Żurowska, Poznań 1993.

WARD J.H., The Notitia Dignitatum, „Latomus” 33 (1974) 397-434.

Ward W.D., From Provincia Arabia to Palaestina Tertia: The Impact of Geography, Economy, and Religion on. Sedentary and Nomadic Communities in the Later Roman Province. of Third Palestine, Los Angeles 2008 (diss.).

Wiewiorowski J., Deformed child in the Twelve Tables, w: Mater Familias. Scritti romanistici per Maria Zabłocka, a cura di Z. Benincasa - J. Urbanik, con la collaborazione di P. Niczyporuk - M. Nowak, Varsovia 2016, 1157-1176.

WIEwIOROwSKI J., Dopuszczalność zabójstwa kalekiego noworodka w pogańskim Rzymie, $\mathrm{w}$ : Zabójstwo dziecka w literaturze i kulturze europejskiej, red. K. Ilski - M. Chmielarz - Z. Kopeć - E. Kraskowska, Badania Interdyscyplinarne 36, Poznań 2016, 23-40.

Wiewiorowski J., Duces Scythiae Minoris. A Prosopographical Study, Poznań 2008.

Wiewiorowski J., Homo religiosus sum, „Czas Kultury” 186 (2015) nr 3, 194-204.

WiEwiorowski J., Insignia of Roman Vicars of Dioceses as Representatives of divine emperors, ,Signa Iuris” 10 (2012) 59-80.

Wiewiorowski J., Prohibition of retroactive law - a historical key to intertemporary law, w: The Intertemporal Problems in Law, ed. by J. Mikołajewicz - W. Szafrański - A. Godek, Poznań 2017, 25-54.

Wiewiorowski J., Sqdownictwo późnorzymskich wikariuszy diecezji, Poznań 2012 = The Judiciary of Diocesan Vicars in the Later Roman Empire, Poznań 2015.

WIEwIOROwSKI J., Stanowisko prawne rzymskich dowódców wojsk prowincjonalnych - duces - w prowincjach Scythia Minor i Moesia Secunda, Poznań 2007.

Wiewiorowski J., Szczególy geograficzne w Notitia dignitatum in partibus Orientis, „U schyłku starożytności - Studia Źródłoznawcze” 12 (2013) 149-181.

Worp K.A., Observations on Some Military Camps and Place Names in Lower Egypt, ZPE 87 (1991) 291-295.

Worp K.A., The Notitia dignitatum and the geography of Egypt: observations on some military camps and place names in Upper Egypt, w: Proceedings of the 20th international congress of papyrologists, Copenhagen, 23-29 August, 1992, ed. by A. Bülow-Jacobsen, Copenhagen 1994, 463-469.

Zahariade M., Scythia Minor. A History of a Later Roman Province (284-681), Amsterdam 2006.

ZAŁUSKi W., Ewolucyjna filozofia prawa, Warszawa 2009.

Netografia

[dostęp: 10 I 2018]

http://bodley30.bodley.ox.ac.uk:8180/luna/servlet/view/all/what/MS.+Canon.+Misc.+ 378? sort

http:/daten.digitale-sammlungen.de/ db/bsb00005863/images/ 
http://eprints.maynoothuniversity.ie/4593/

http://notitiadignitatum.org/

https://commons.wikimedia.org/wiki/File:Notitia_Dignitatum_-_Comes_per_Isauriam.jpg https://en.wikipedia.org/wiki/Peronet_Lamy

https://upload.wikimedia.org/wikipedia/commons/2/22/Notitia_Dignitatum_-_Dux_Thebaidos.jpg

https://upload.wikimedia.org/wikipedia/commons/3/36/Notitia_Dignitatum_-_Comes_limitis_Aegypti.jpg

https://upload.wikimedia.org/wikipedia/commons/5/50/Notitia_Dignitatum_-_Dux_Armeniae.jpg

https://upload.wikimedia.org/wikipedia/commons/6/68/Notitia_Dignitatum_-_Dux_Palestinae.jpg

https://upload.wikimedia.org/wikipedia/commons/7/78/Notitia_Dignitatum_-_Dux_Mesopotamiae.jpg

https://upload.wikimedia.org/wikipedia/commons/8/81/Notitia_Dignitatum_-_Dux_Scythiae.jpg

https://upload.wikimedia.org/wikipedia/commons/9/94/Notitia_Dignitatum_-_Dux_Arabiae.jpg

https://www.frontiersin.org/articles/10.3389/fpsyg.2015.00368/full

https://www.nature.com/articles/srep46331

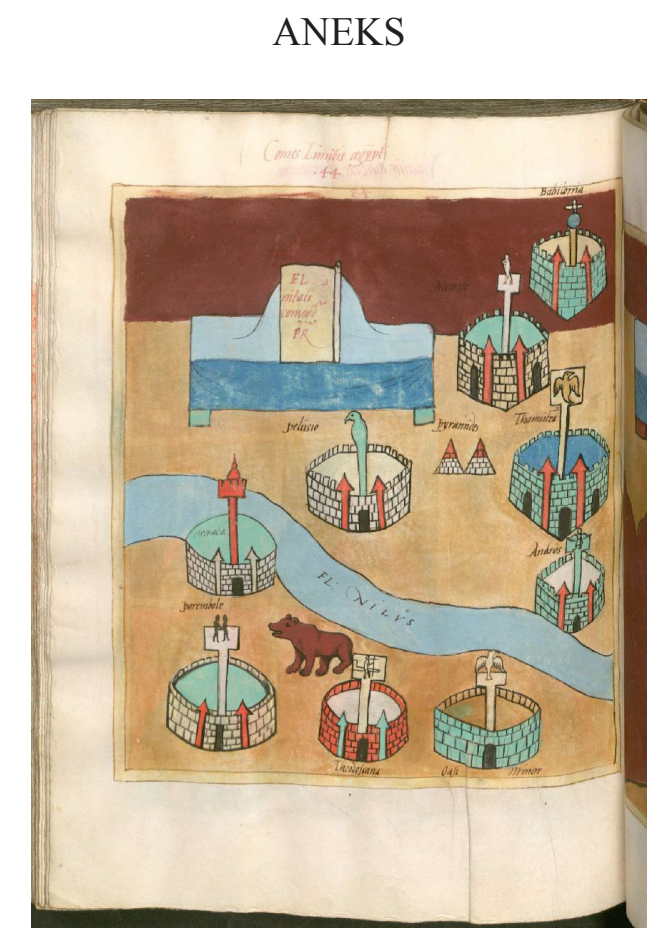

Il. 1a. Insygnia comes limitis Aegypti - Not. Dig. Or. 28 (MONACENSIS LATINUS 10291), (C) Bayerische Staatsbibliothek, München, Clm 10291. 


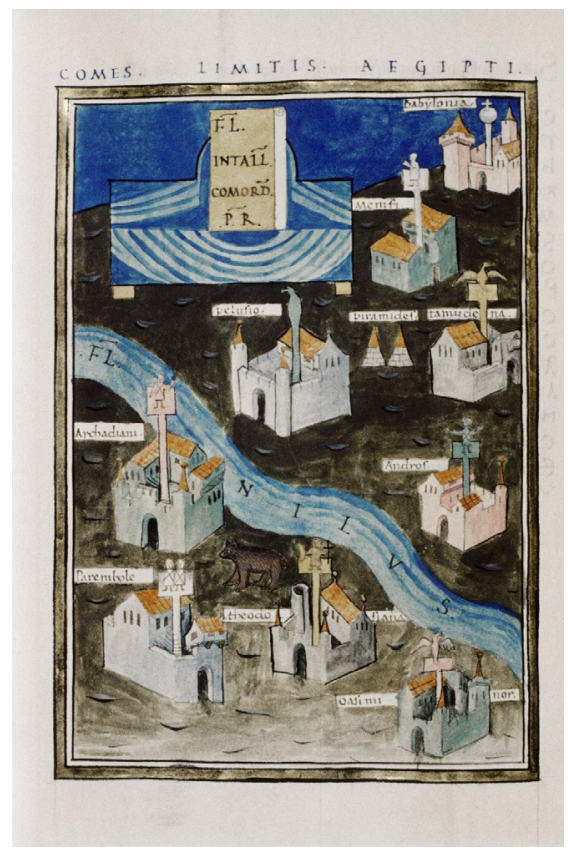

Il. 1b: Insygnia comes limitis Aegypti - Not. Dig. Or. 28 (OXONIENSIS CANONICIANUS MISC. 378), https://upload.wikimedia.org/wikipedia/commons/3/36/Notitia_Dignitatum_-_Comes_limitis_Aegypti.jpg.

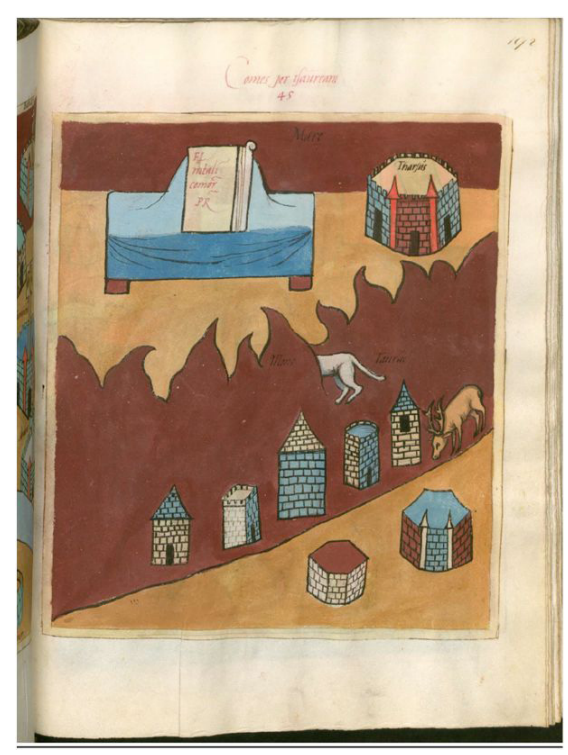

I1. 2a: Insygnia comes per Isauriam - Not. Dig. Or. 29 (MONACENSIS LATINUS 10291), (C Bayerische Staatsbibliothek, München, Clm 10291. 


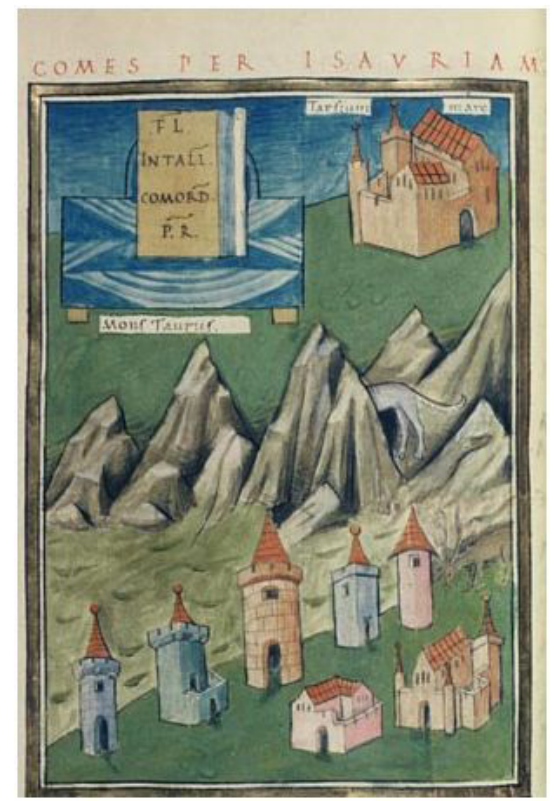

Il. 2b. Insygnia comes per Isauriam - Not. Dig. Or. 29 (OXONIENSIS CANONICIANUS MISC. 378), https://commons.wikimedia.org/wiki/File:Notitia_Dignitatum_-_Comes_per_Isauriam.jpg.

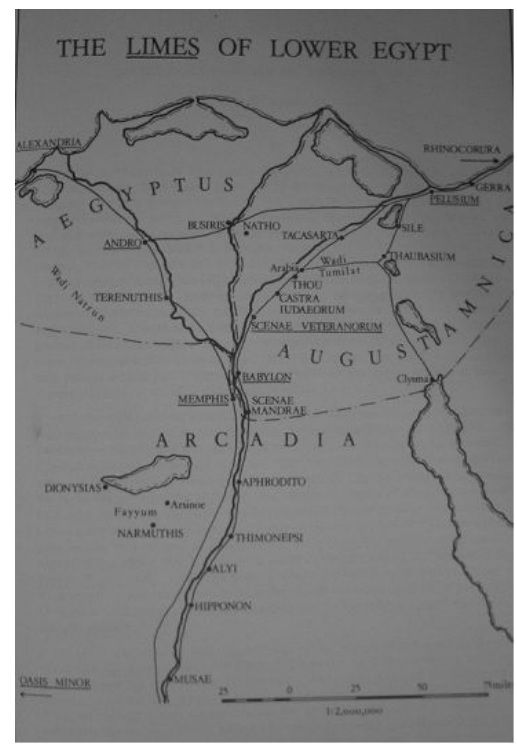

Il. 3. Limes w dolnym Egipcie na przełomie IV i V w. według: R.M. Price, The limes of Lower Egypt, w: Aspects of the Notitia Dignitatum, ed. R. Goodburn - R. Bartholemew (eds.), BAR, Supplementum series 15, Oxford 1976, 155. 


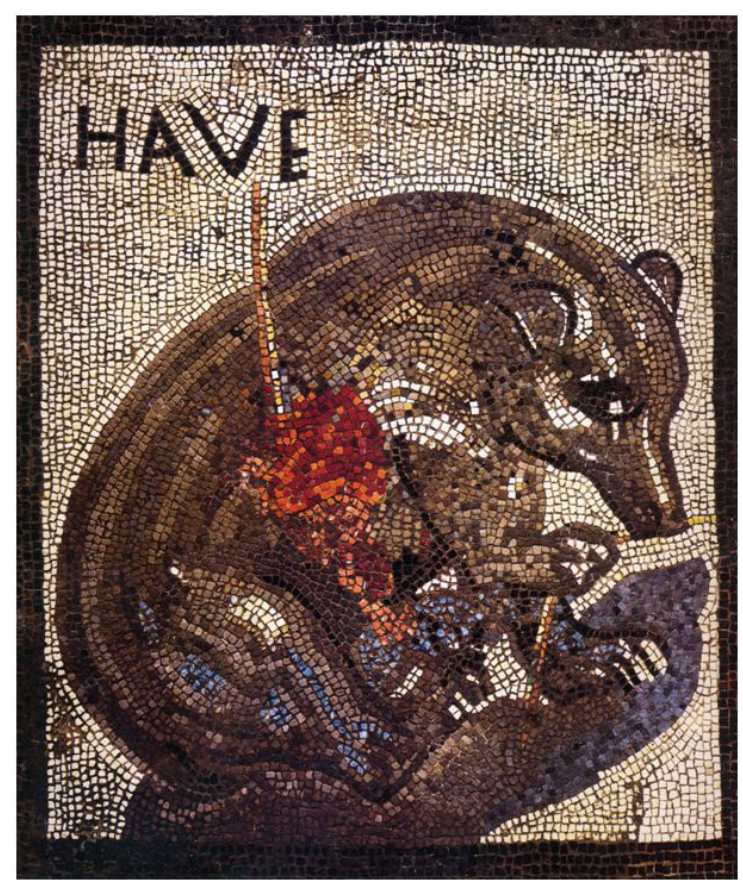

Il. 4. Niedźwiedż (Ursus arctos) - mozaika pompejańska (Casa dell'Orso ferito), https://upload.wikimedia.org/wikipedia/commons/3/3d/Pompeii_-_Casa_dell_Orso_Ferito_-_Bear_Mosaic.jpg.

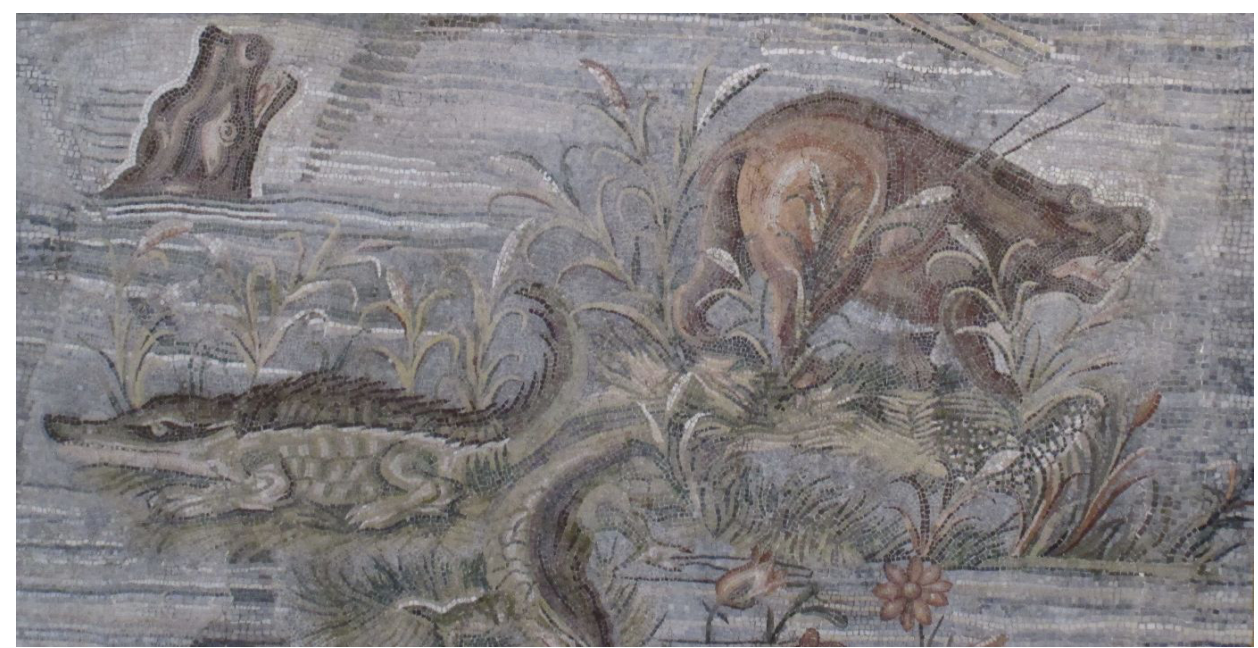

Il. 5a. Hipopotam nilowy (Hippopotamus amphibius), Mozaika z Palestriny (fragment), https://upload.wikimedia.org/wikipedia/commons/2/2a/Hippos_and_Crocs_among_ Reeds_in_Nile_River_Mosaic.png. 


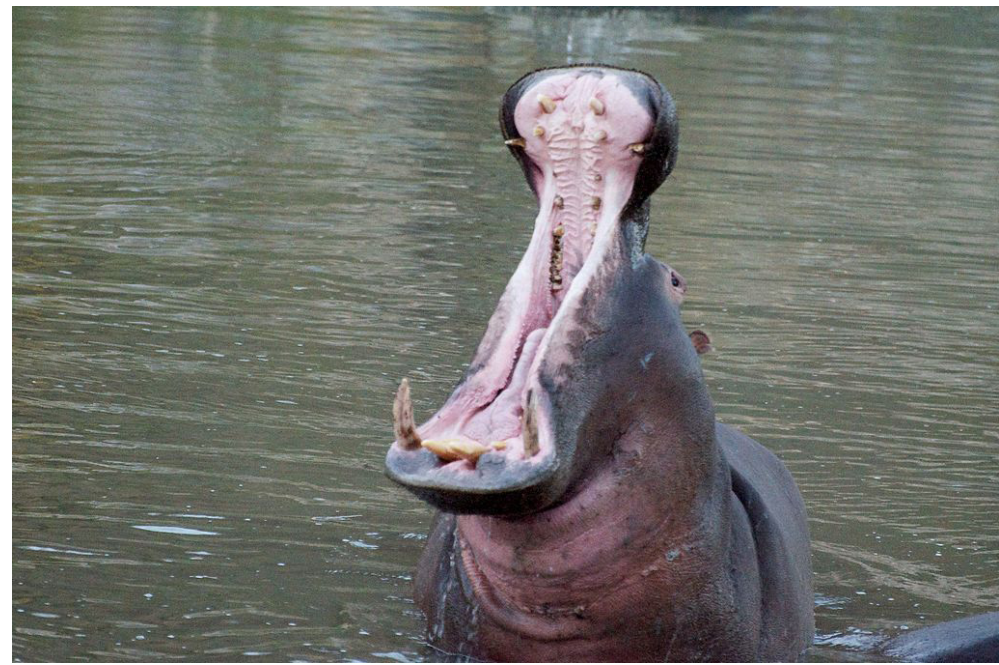

Il. 5b. https://en.wikipedia.org/wiki/Hippopotamus\#/media/File:Hippo_mouth_opening.jpg.

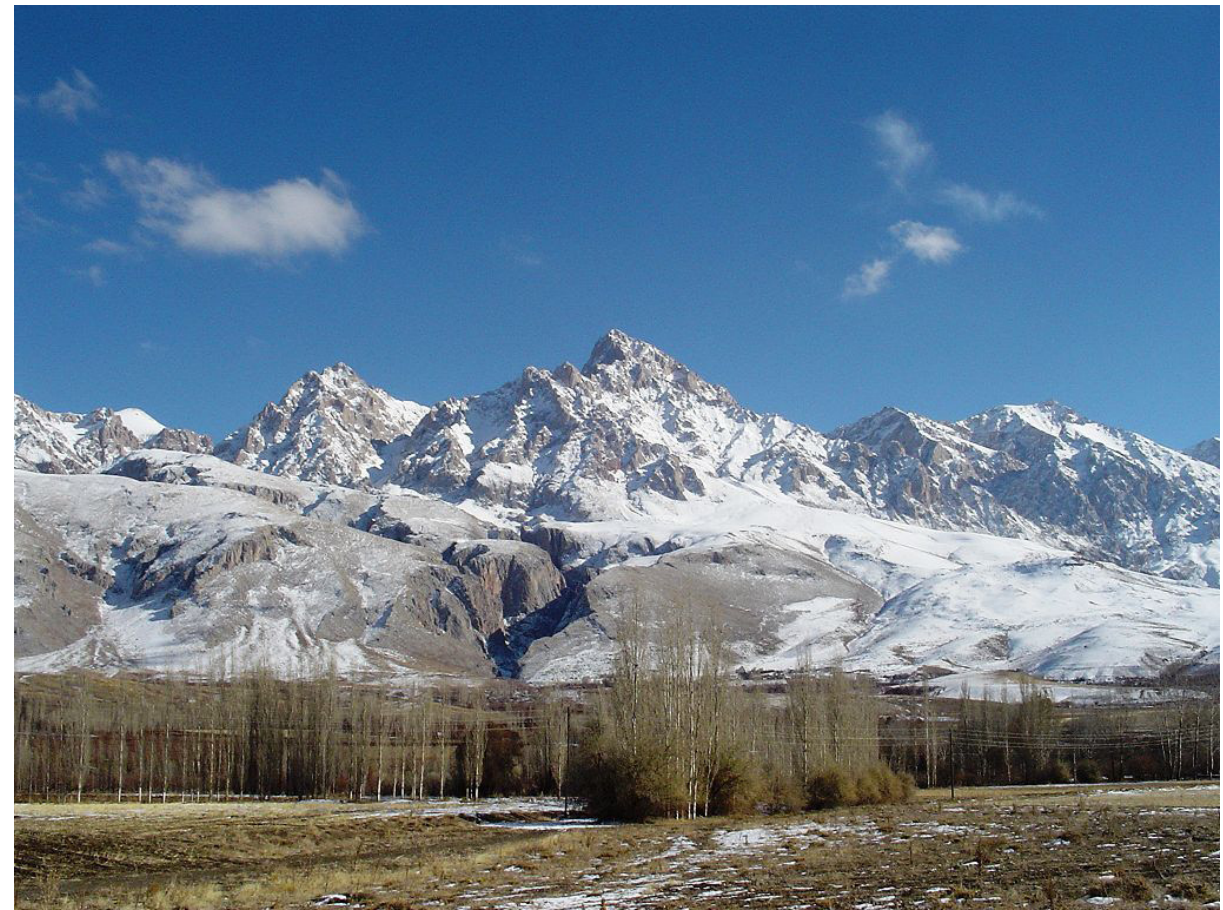

Il. 6a. Góry Taurus, według: https://en.wikipedia.org/wiki/Taurus_Mountains\#/media/File:Demirkazik_Crest_of_Aladag_Mountains_in_Nigde_Turkey.jpg. 


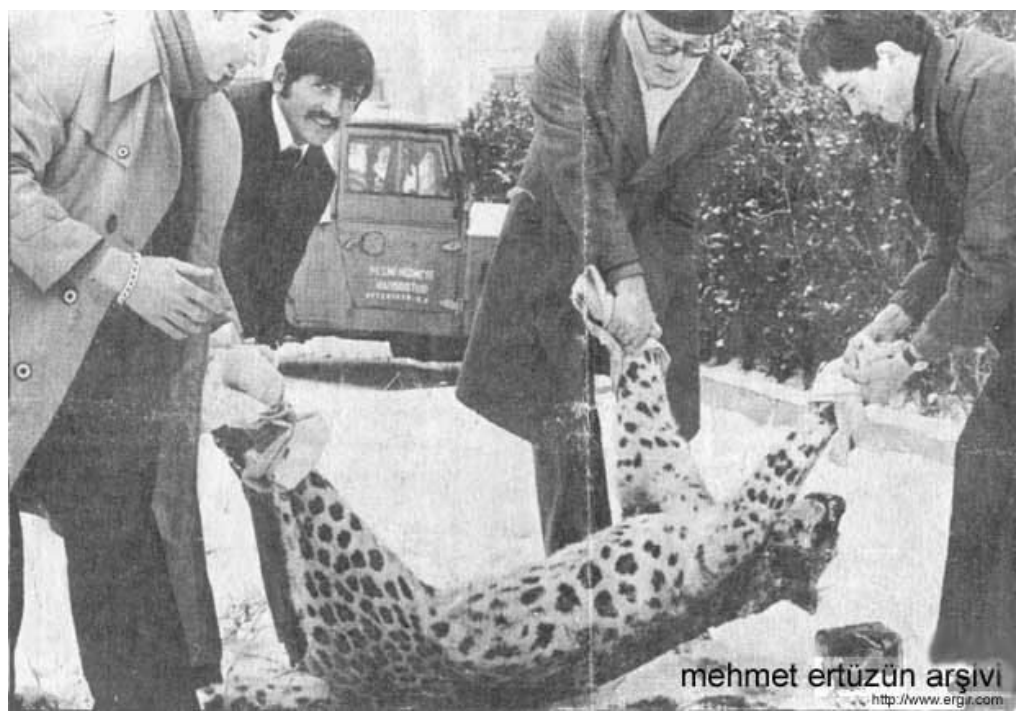

Il. 6b. Pantera - Panthera pardus tulliana, http://www.ergir.com/last_anatolian_panther.htm.

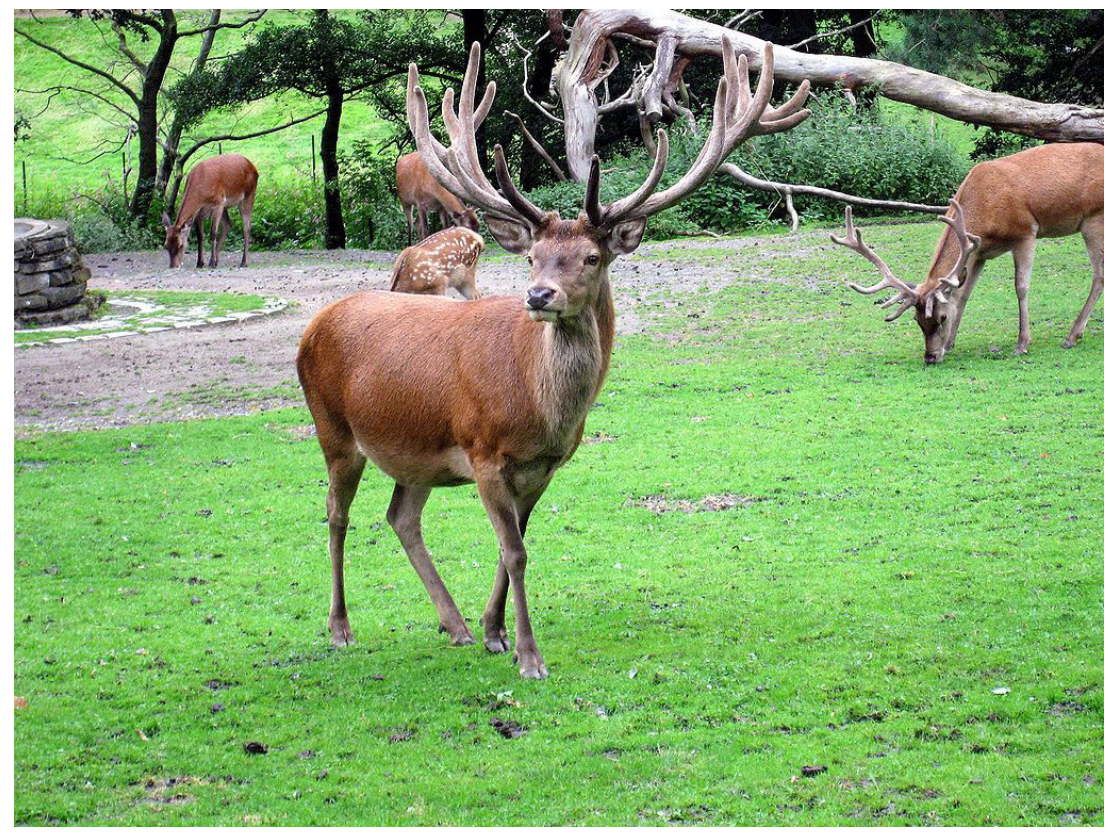

Il. 6c. Jeleń szlachetny (Cervus elaphus), https://pl.wikipedia.org/wiki/Jele\%C5\%84 szlachetny\#/media/File:Zoo-Dortmund-IMG_5513.JPG. 


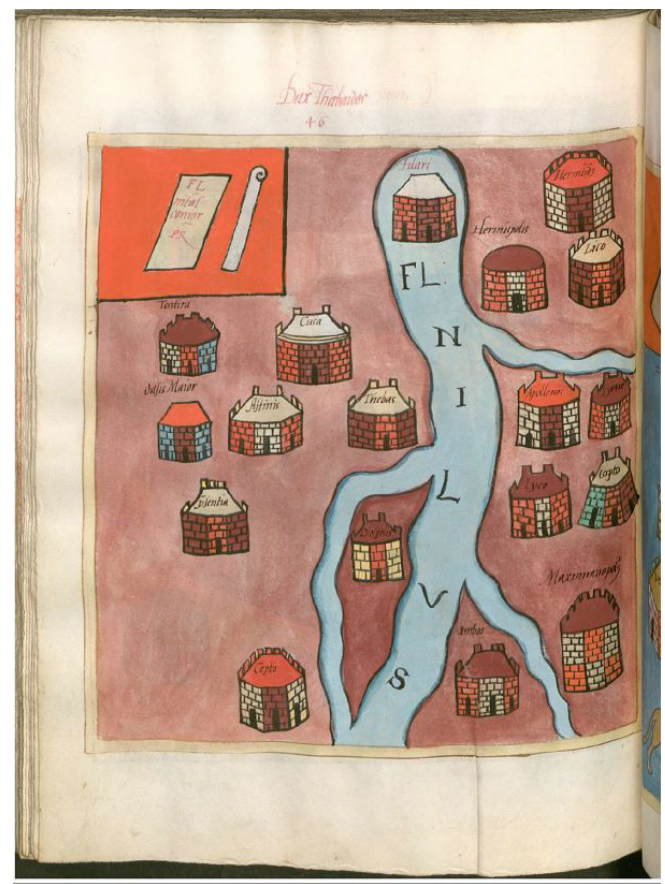

Il. 7a. Insygnia dux Thebaidos - Not. Dig. Or. 31 (MONACENSIS LATINUS 10291), (C) Bayerische Staatsbibliothek, München, Clm 10291.

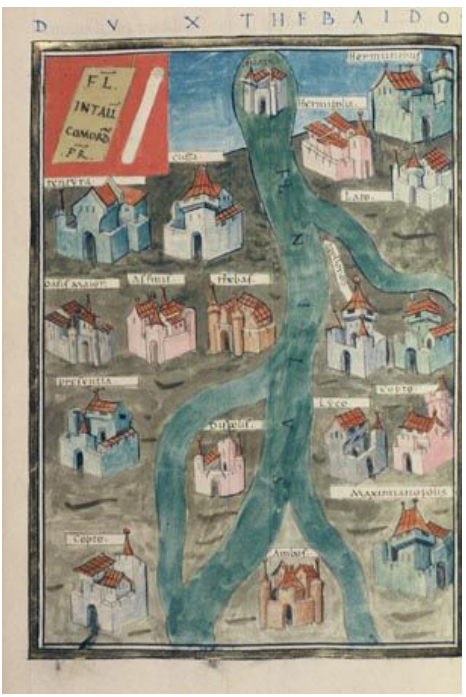

Il. 7b. Insygnia dux Thebaidos - Not. Dig. Or. 31 (OXONIENSIS CANONICIANUS MISC. 378), https://upload.wikimedia.org/wikipedia/commons/2/22/Notitia_Dignitatum_Dux_Thebaidos.jpg. 


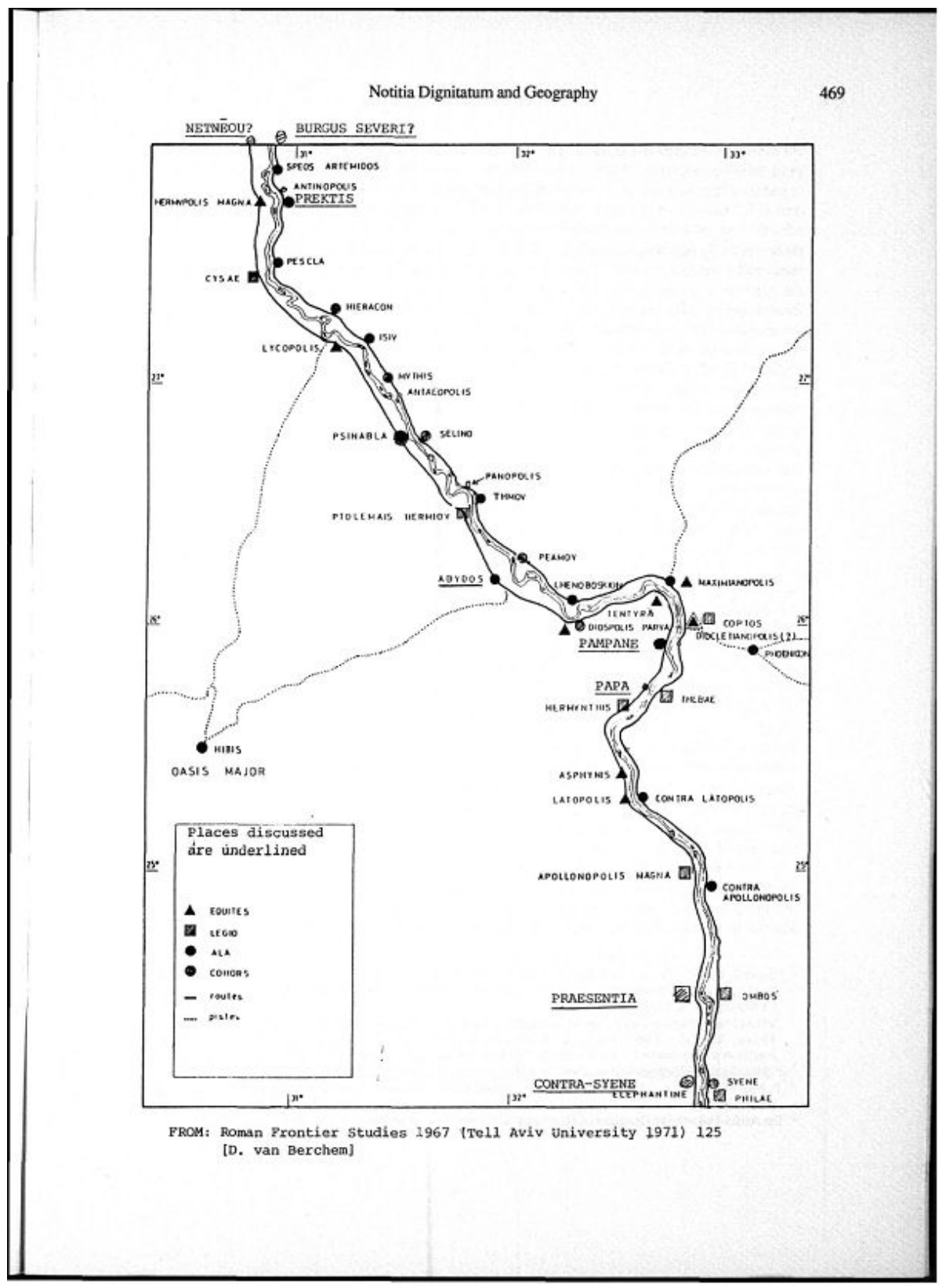

Il. 8. Umocnienia IV-V w. - Thebaida, według: K.A. Worp, The Notitia dignitatum and the geography of Egypt: observations on some military camps and place names in Upper Egypt, w: Proceedings of the $20^{\text {th }}$ international congress of papyrologists (Copenhagen, 23-29 August, 1992), ed. A. Bülow-Jacobsen, Copenhagen 1994, 469. 


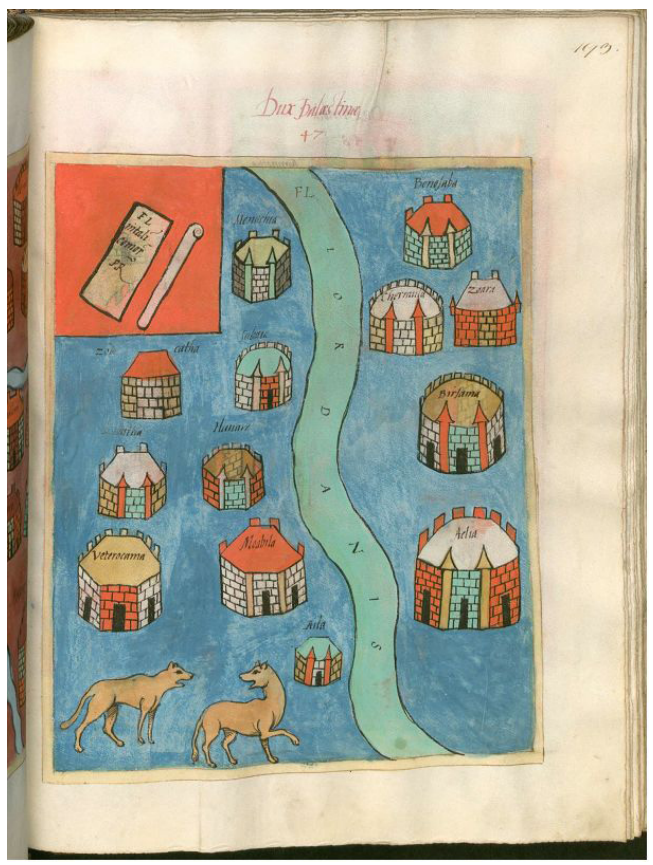

Il. 9a. Insygnia dux Palestiane - Not. Dig. Or. 34 (MONACENSIS LATINUS 10291), (C) Bayerische Staatsbibliothek, München, Clm 10291.

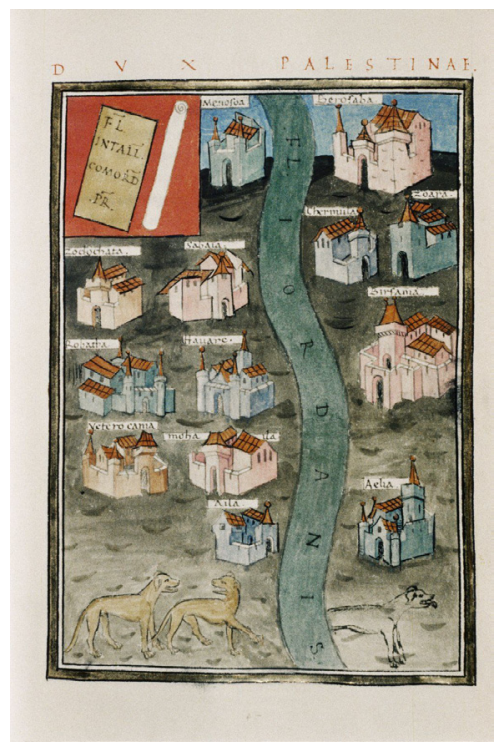

Il. 9b. Insygnia dux Palestinae - Not. Dog. Or. 34 (OXONIENSIS CANONICIANUS MISC. 378), https://upload.wikimedia.org/wikipedia/commons/6/68/Notitia_Dignitatum_-_ Dux_Palestinae.jpg. 


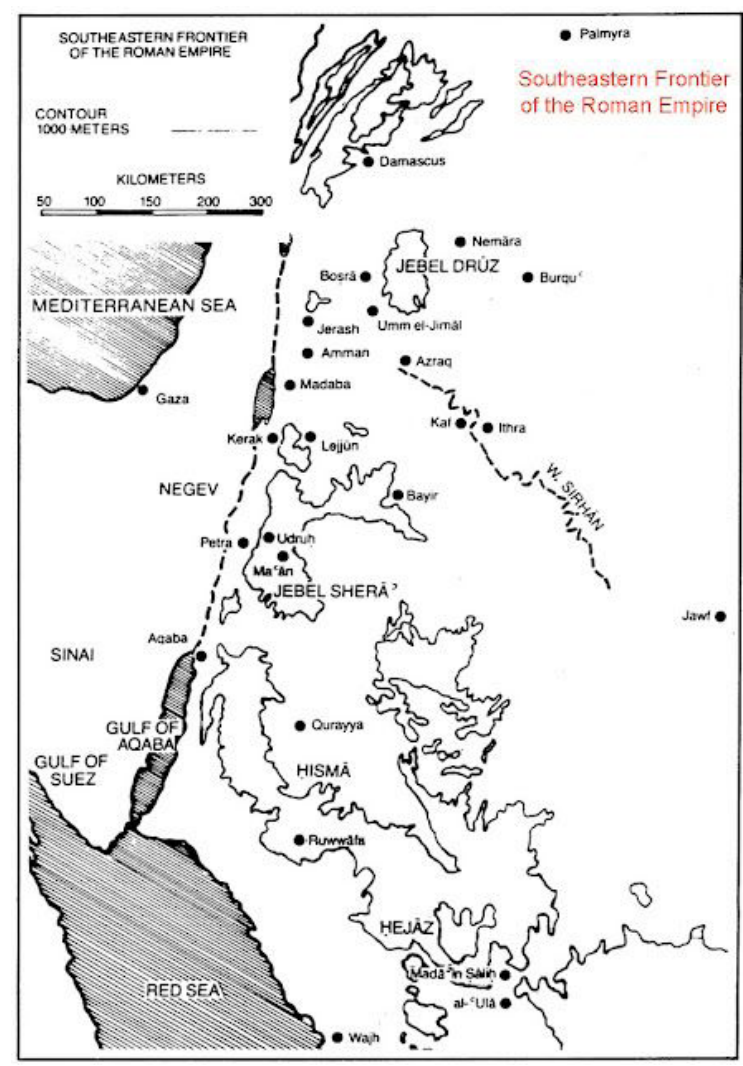

Il. 10a. Miejsca umocnione na terenie Palestyny i Arabii w IV-V w. według: G. Linton, w: https://documentslide.org/roman-forts-on-the-arabian-frontier; http://byzantinemilitary.blogspot.com/2012/08/

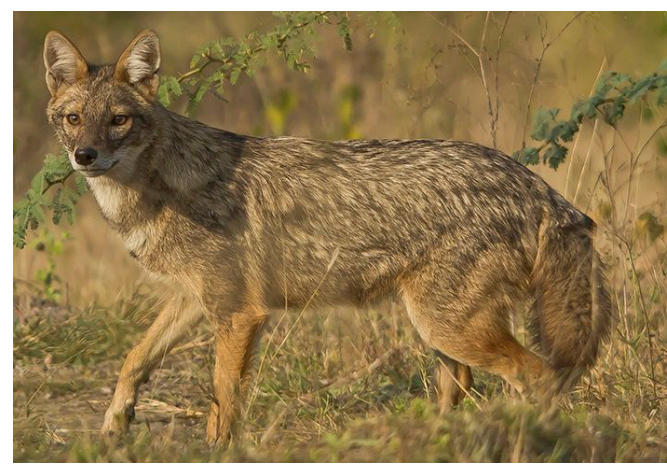

Il. 10b. Szakal złocisty (Canis aureus), https://en.wikipedia.org/wiki/Golden_jackal\#/ media/File:Golden_Jackal_at_Rajkot_2_(cropped).jpg. 


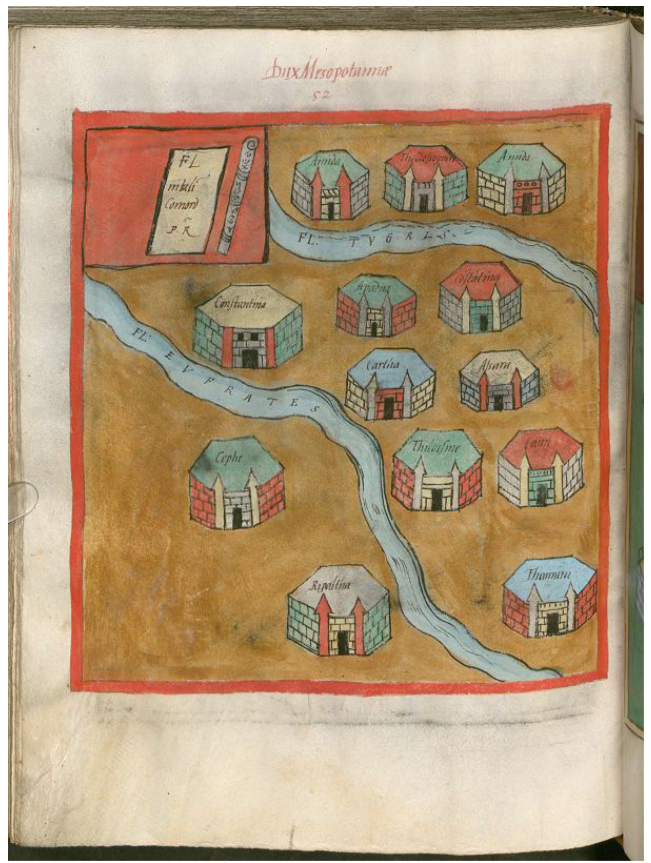

Il. 11a. Insygnia dux Mesopotamiae - Not. Dig. Or. 36 (MONACENSIS LATINUS 10291), (C) Bayerische Staatsbibliothek, München, Clm 10291.

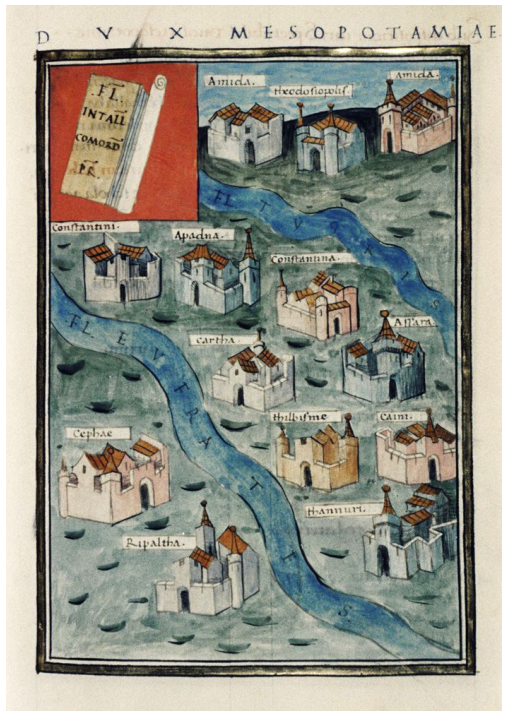

Il. 11b. Insygnia dux Mesopotamiae - Not. Dig. Or. 36 (OXONIENSIS CANONICIANUS MISC. 378), https://upload.wikimedia.org/wikipedia/commons/7/78/Notitia_Dignitatum_-_Dux_Mesopotamiae.jpg. 


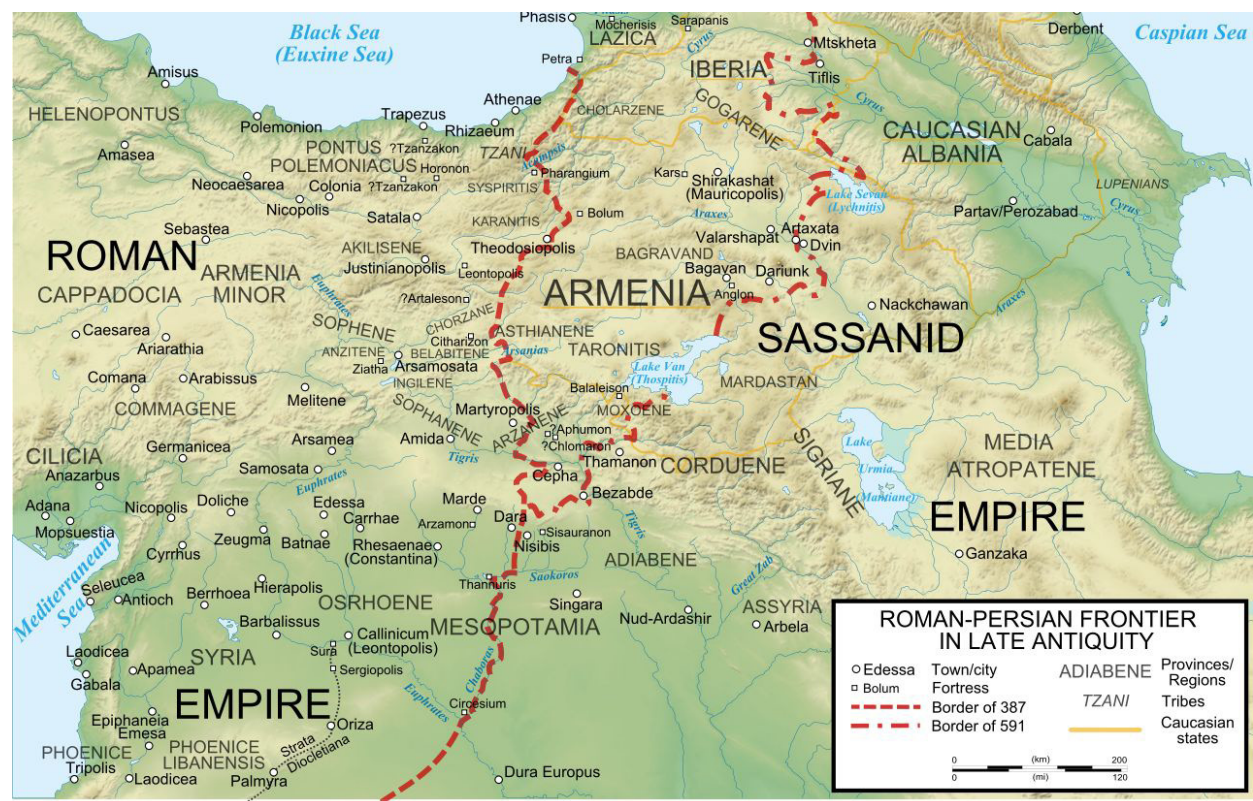

Il. 12. Pogranicze rzymsko-perskie IV-V w., https://en.wikipedia.org/wiki/Byzantine$\%$ E2\%80\%93Sasanian_wars\#/media/File:Roman-Persian_Frontier_in_Late_Antiquity.svg.

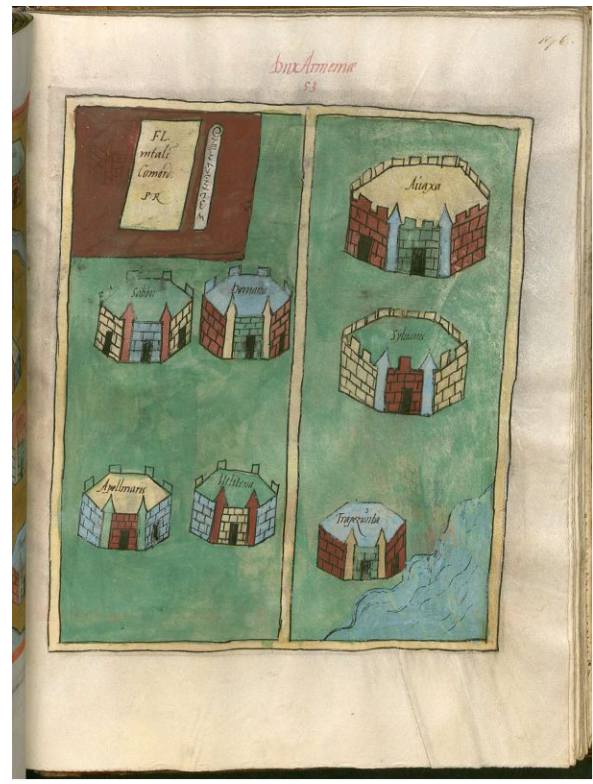

Il. 13a. Insygnia dux Armeniae - Not. Dig. Or. 38 (MONACENSIS LATINUS 10291), (C) Bayerische Staatsbibliothek, München, Clm 10291. 


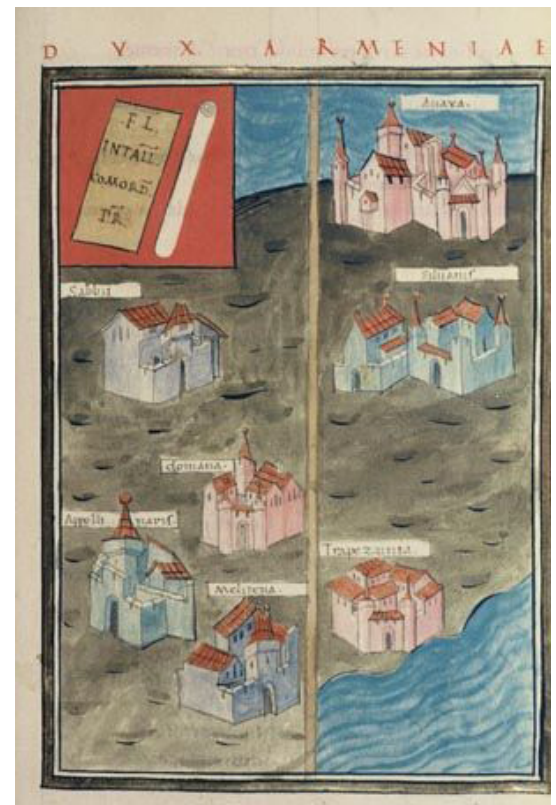

Il. 13b. Insygnia dux Armeniae - Not. Dig. Or. 38 (OXONIENSIS CANONICIANUS MISC. 378), https://upload.wikimedia.org/wikipedia/commons/5/50/Notitia_Dignitatum_-Dux_Armeniae.jpg.

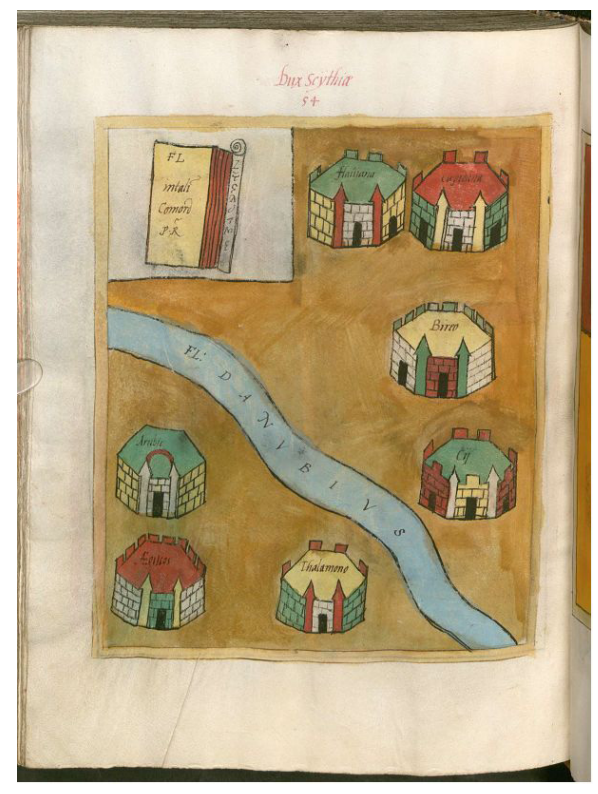

Il. 14a. Insygnia dux Scythiae - Not. Dig. Or. 39 (MONACENSIS LATINUS 10291), (c) Bayerische Staatsbibliothek, München, Clm 10291. 


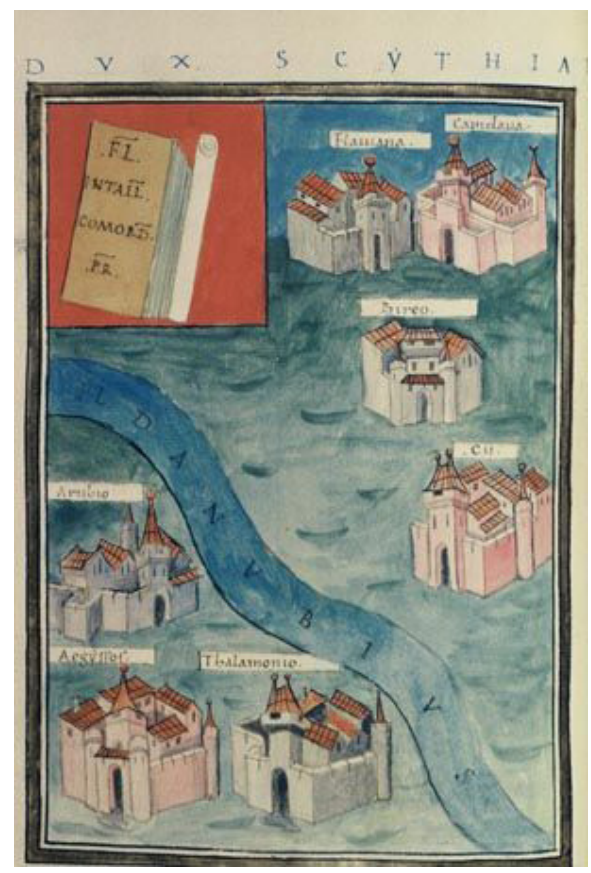

Il. 14b. Insygnia dux Scythiae - Not. Dig. Or. 39 (OXONIENSIS CANONICIANUS MISC. 378), https://upload.wikimedia.org/wikipedia/commons/8/81/Notitia_Dignitatum_Dux_Scythiae.jpg.

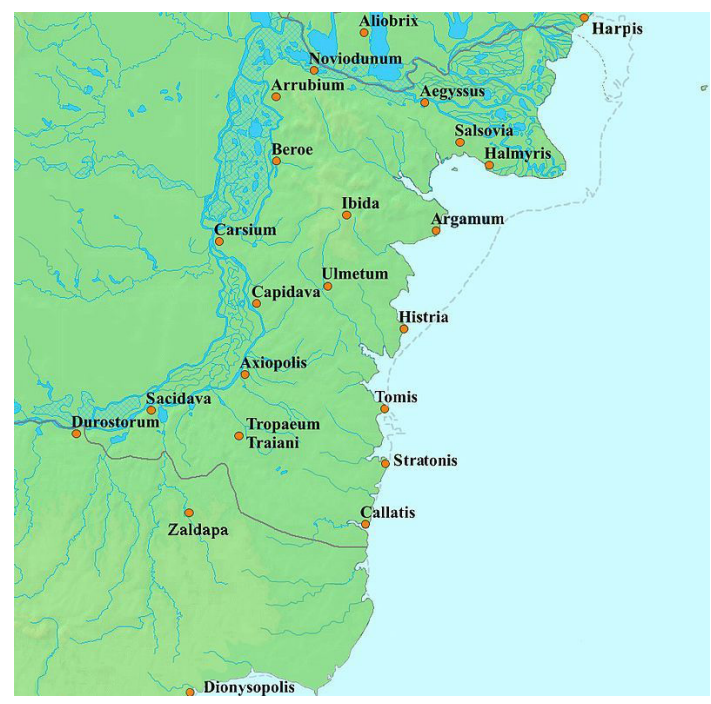

I1. 15. Prowincja Scythia Minor, https://de.wikipedia.org/wiki/Scythia_Minor\#/media/File:Scythia_Minor_map.jpg. 


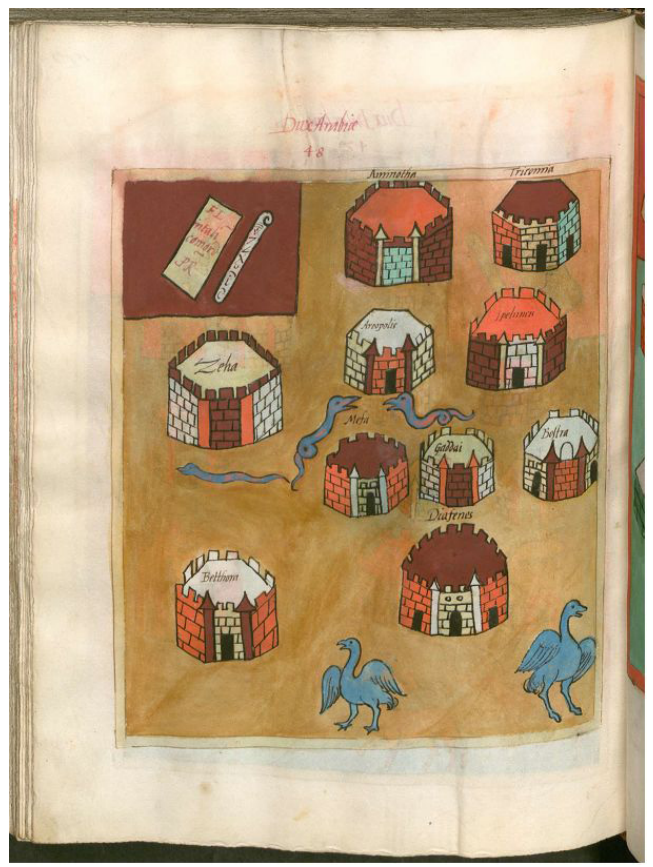

Il. 16a. Insygnia dux Arabiae - Not. Dig. Or. 37 (MONACENSIS LATINUS 10291), (C) Bayerische Staatsbibliothek, München, Clm 10291.

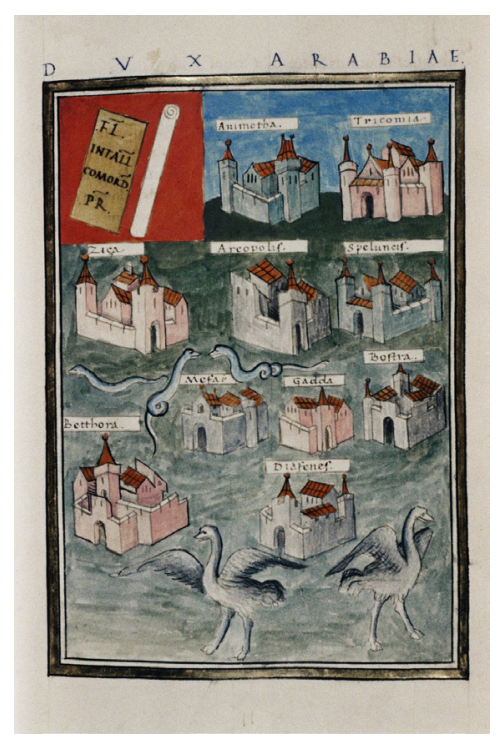

Il. 16b. Insygnia dux Arabiae - Not. Dig. Or. 37 (OXONIENSIS CANONICIANUS MISC. 378), https://upload.wikimedia.org/wikipedia/commons/9/94/Notitia_Dignitatum_-Dux_Arabiae.jpg. 


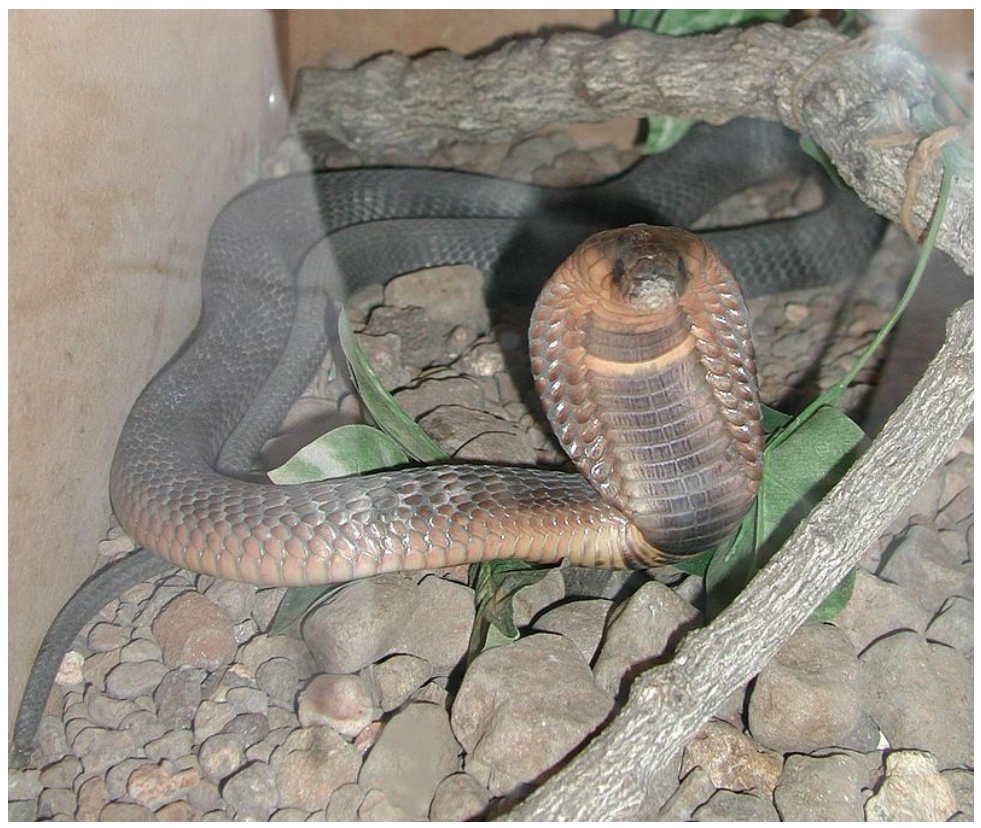

Il. 17a. Kobra egipska (Naja haje), https://pl.wikipedia.org/wiki/Kobra_egipska\#/media/File:L14cobra.jpg.

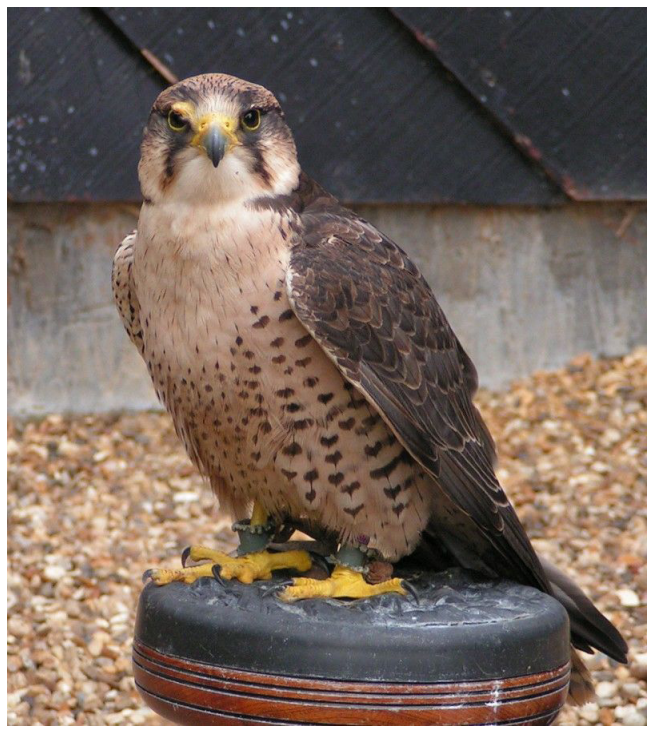

Il. 17b. Raróg górski (Falco biarmicus), https://pl.wikipedia.org/wiki/Rar\%C3\%B3g_g\%C3\%B3rski\#/media/File:Lanner_Falcon_800.jpg. 